\title{
A new butterfly species from south Russia revealed through chromosomal and molecular analysis of the Polyommatus (Agrodiaetus) damonides complex (Lepidoptera, Lycaenidae)
}

\author{
Vladimir A. Lukhtanov ${ }^{1,2}$, Alexander V. Dantchenko³ \\ I Department of Karyosystematics, Zoological Institute of the Russian Academy of Sciences, Universitetskaya \\ nab. 1, St. Petersburg 199034, Russia 2 Department of Entomology, St. Petersburg State University, Universi- \\ tetskaya nab 7/9, St. Petersburg 199034, Russia 3 Faculty of Chemistry, Lomonosov Moscow State University, \\ GSP-1, Leninskiye Gory 1/13, Moscow119991, Russia
}

Corresponding author: Vladimir A. Lukhtanov (lukhtanov@mail.ru)

Academic editor: C. Nokkala | Received 6 August 2017 | Accepted 22 October 2017 | Published 24 November 2017

http://zoobank.org/2C6D1EF0-B7C5-47F3-A5C9-D200A423B40D

Citation: Lukhtanov VA, Dantchenko AV (2017) A new butterfly species from south Russia revealed through chromosomal and molecular analysis of the Polyommatus (Agrodiaetus) damonides complex (Lepidoptera, Lycaenidae). Comparative Cytogenetics 11(4) 769-795. https://doi.org/10.3897/CompCytogen.v11i4.20072

\begin{abstract}
Finding a new species is a rare event in easy-to-see and well-studied organisms like butterflies, especially if they inhabit well-explored areas such as the Western Palaearctic. However, even in this region, gaps in taxonomic knowledge still exist and here we report such a discovery. Using a combined analysis of chromosomal and molecular markers we demonstrate that Polyommatus blue populations from Daghestan (South Russia), previously identified as $P$. aserbeidschanus, represent in fact a new species which is described here as $P$. australorossicus sp. $\mathbf{n}$. We also show that the enigmatic Polyommatus damonides described as a form of Polyommatus damone and later considered as an entity similar to $P$. poseidon or $P$. ninae is conspecific with a taxon previously known as $P$. elbursicus. As a result of our study, we propose several taxonomic changes within the $P$. damonides species complex and suggest the following new combinations: $P$. damonides elbursicus Forster, 1956, comb. n. and $P$. damonides gilanensis Eckweiler, 2002, comb. n.
\end{abstract}

\section{Keywords}

Ancestral polymorphism, biodiversity, chromosomes, chromosomal fusion/fission, COI, cryptic species, DNA barcoding, incomplete lineage sorting, inverted meiosis, karyosystematics, molecular phylogenetics, mitochondrial introgression, phylogeography, speciation

Copyright Vladimir A.Lukhtanov, AlexanderV. Dantchenko. This is an open access article distributed under the terms of the Creative Commons Attribution License (CC BY 4.0), which permits unrestricted use, distribution, and reproduction in any medium, provided the original author and source are credited. 


\section{Introduction}

Agrodiaetus Hübner, 1822, a subgenus of the species-rich Palaearctic genus Polyommatus Latreille, 1804 (Talavera et al. 2013), includes numerous species, subspecies and forms with uncertain taxonomic positions (de Lesse 1960a, b, Eckweiler and Häuser 1997, Häuser and Eckweiler 1997, Olivier et al. 1999, Carbonell 2000, 2001, Dantchenko 2000a, Przybyłowicz 2000, ten Hagen and Eckweiler 2001, Skala 2001, Lukhtanov and Dantchenko 2002a, b, Kandul et al. 2004, Wiemers 2003, Schurian and ten Hagen 2003, Vila et al. 2010, Talavera et al. 2013, Eckweiler and Bozano 2016). It was estimated to have originated only about 3 million years ago (Kandul et al. 2004) and radiated rapidly in the Western Palaearctic (Kandul et al. 2007). The last published review of the subgenus includes 120 valid species (Eckweiler and Bozano 2016). Many of them have extremely local 'dot-like' distributions that are restricted to particular mountain valleys in the Balkan Peninsula, Asia Minor, Transcaucasus, Iran and Central Asia (Vila et al. 2010, Lukhtanov et al. 2015a,b, Eckweiler and Bozano 2016, Vishnevskaya et al. 2016). This subgenus is a model system in studies of speciation (Lukhtanov et al. 2005, Wiemers et al. 2009), intraspecific differentiation (Dincă et al. 2013, Przybyłowicz et al. 2014), and rapid karyotype evolution (Lukhtanov and Dantchenko 2002a, Kandul et al. 2007, Vershinina and Lukhtanov 2013, 2017).

Species identification in Agrodiaetus is complicated. The morphology of male genitalia is uniform for most of the species. With a few exceptions, it can help to separate groups of species (Coutsis 1986), but not individual species. The differences in wing pattern and coloration (Eckweiler and Bozano 2016) as well as in the number of antennal segments (Carbonell 1993) are very subtle or nearly lacking between many Agrodiaetus species. The specific pubescence of costal area of forewings may be a useful morphological character to separate species in syntopy (Dantchenko and Churkin 2003), but it works only in certain cases. In spite of morphological similarity, the taxonomic and identification problems within the subgenus Agrodiaetus can be solved if chromosomal (de Lesse 1960a,b, Lukhtanov 1989) or molecular markers (Wiemers 2003, Kandul et al. 2004, 2007, Lukhtanov et al. 2005, Stradomsky and Fomina 2013), or their combination (Lukhtanov et al. 2006, 2008, 2014, 2015a,b, Vila et al. 2010, Lukhtanov and Tikhonov 2015, Shapoval and Lukhtanov 2015a, b) are applied. An unusual diversity of karyotypes is the most remarkable characteristic of Agrodiaetus. Species of this subgenus exhibit one of the highest ranges in chromosome numbers in the animal kingdom (Lukhtanov 2015). Haploid chromosome numbers (n) in Agrodiaetus range from $\mathrm{n}=10$ in $P$. (A.) caeruleus (Staudinger, 1871) to $\mathrm{n}=134$ in $P$. (A.) shahrami (Skala, 2001) (Lukhtanov and Dantchenko 2002a, Lukhtanov et al. 2005). Additionally, this subgenus demonstrates a high level of karyotypic differentiation with respect to chromosome size (Lukhtanov and Dantchenko 2002b) and variation in number of chromosomes bearing ribosomal DNA clusters (Vershinina et al. 2015). These differences provide reliable characters for species delimitation, description and identification (de Lesse 1960a, b, Lukhtanov and Dantchenko 2002a, b). 
Here we use a combination of molecular mitochondrial (COI) and nuclear chromosomal (karyotype) markers to analyze the taxa and populations close to Polyommatus damonides (= lineage VIII in Kandul et al. 2004). This group includes the following species: P. ninae (Forster, 1956), P. aserbeidschanus (Forster, 1956), P. australorossicus sp. n., P. damonides (Staudinger, 1899), P. lukhtanovi (Dantchenko, 2005), P. zarathustra Eckweiler, 1997, P. arasbarani (Carbonell \& Naderi, 2000) and P. pierceae (Lukhtanov \& Dantchenko, 2002). Here we do not analyze the distantly related taxa $P$. paulae Wiemers \& De Prins J., 2004, P. huberti (Carbonell, 1993), P. turcicolus (Koçak, 1977), P. zapvadi (Carbonell, 1993), P. avajicus (Blom, 1979) and P. zardensis Schurian $\&$ ten Hagen, 2001 which will be considered in later publications. The taxa of the P. damonides species complex were revised by Forster $(1956,1960,1961)$, de Lesse (1963), Lukhtanov (1989), Carbonell (1993), Hesselbarth et al. (1995), Carbonell and Naderi (2000), Dantchenko (2000b, 2005) and Eckweiler and Bozano (2016). However, the species-level boundaries remain poorly defined in this complex.

\section{Material and methods}

\section{Samples}

Specimens examined (Supplementary Table 1, Fig. 1) are deposited in the Zoological Institute of the Russian Academy of Sciences, St. Petersburg, Russia and in the McGuire Center for Lepidoptera and Biodiversity (MGCL), Florida Museum of Natural History, University of Florida, Gainesville, Florida, USA.

\section{Chromosomal analysis}

Karyotypes were obtained from 157 adult males representing eight species and were processed as previously described (Lukhtanov et al. 2014, 2015a, Vishnevskaya et al. 2016). Briefly, gonads were removed from the abdomen and placed into freshly prepared fixative (3:1;96\% ethanol and glacial acetic acid) directly after capturing the butterfly in the field. Testes were stored in the fixative for 3-36 months at $+4^{\circ} \mathrm{C}$. Then the gonads were stained in $2 \%$ acetic orcein for $30-60$ days at $+18-20^{\circ} \mathrm{C}$. Different stages of male meiosis, including metaphase I (MI) and metaphase II (MII) were examined using an original two-phase method of chromosome analysis (Lukhtanov and Dantchenko 2002, Lukhtanov et al. 2006). In some cases diploid chromosome numbers $(2 \mathrm{n})$ were counted in atypical meiosis (see Lorković 1990 for a review of atypical meiosis in Lepidoptera). Abbreviation $c a$ (circa) means that the count was made with an approximation due to an insufficient quality of preparation or overlapping of some chromosomes or bivalents. 


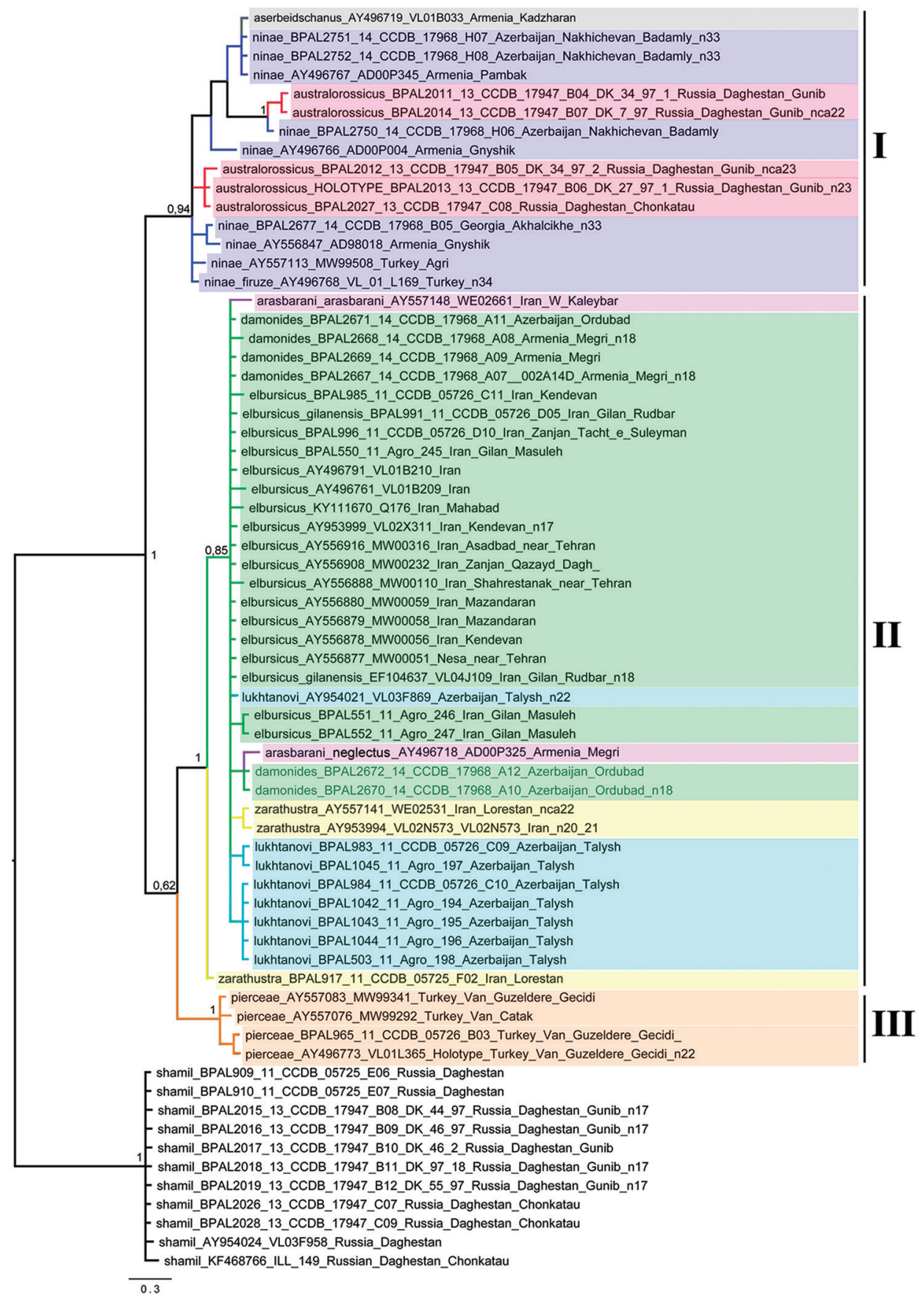

Figure I. The Bayesian tree of studied Polyommatus samples based on analysis of the cytochrome oxidase subunit I (COI) gene. Numbers at nodes indicate Bayesian posterior probability. I, II and III are recovered haplogroups of the $P$. damonides species complex. Polyommatus shamil, phenotypically similar to $P$. australorossicus, but genetically distant, was used to root the tree. 


\section{Molecular methods and DNA barcode-based phylogeographic study}

Standard COI barcodes (658-bp 5' segment of mitochondrial cytochrome oxidase subunit I) were studied. COI sequences were obtained from 30 specimens representing the $P$. damonides species group and from 9 samples of $P$. shamil (Dantchenko, 2000) which was selected as outgroup. Legs were sampled from these specimens, and sequence data from the DNA barcode region of $C O I$ were obtained at the Canadian Centre for DNA Barcoding (CCDB, Biodiversity Institute of Ontario, University of Guelph) using protocols described in Hajibabaei et al. (2005), Ivanova et al. (2006) and deWaard et al. (2008). Photographs of these specimens, as well as collecting data are available in the Barcode of Life Data System (BOLD), project Butterflies of Palearctic (BPAL) at http://www.boldsystems.org/. Field codes and collecting data of these samples are also shown in Figure 1.

We also used 28 published COI sequences (Wiemers 2003, Kandul et al. 2004, Lukhtanov et al. 2005, Kandul et al. 2007, Wiemers and Fiedler 2007, Shapoval and Lukhtanov 2016) which were downloaded from GenBank. Their accession numbers are shown in Figure 1.

The barcode analysis involved 67 COI sequences. Sequences were aligned using the BioEdit software (Hall 1999) and edited manually. Phylogenetic hypotheses were inferred using Bayesian inference as described previously (Vershinina and Lukhtanov 2010, Lukhtanov et al. 2016a, b). Briefly, the Bayesian analysis was performed using the program MrBayes 3.2 (Ronquist et al. 2012) with default settings as suggested by Mesquite (Maddison and Maddison 2015): burn-in=0.25, nst=6 (GTR + I + G). Two runs of 10,000,000 generations with four chains (one cold and three heated) were performed. The consensus of the obtained trees was visualised using FigTree 1.3.1 (http:// tree.bio.ed.ac.uk/software/figtree/).

\section{Results}

\section{Karyotypes}

157 specimens were karyotyped (Supplementary Table 1, Figs 2-7).

\section{P. ninae (Fig. 2a-e)}

At the MI/MII stages, the number of chromosome elements was found to vary from $\mathrm{n}=\mathrm{ca} 32$ to $\mathrm{n}=34-36$ in 21 studied specimens from different localities, with $\mathrm{n}=33$ and $\mathrm{n}=34$ as distinct modal numbers. All chromosome elements formed a gradient size row. The species seemed to be polymorphic for at least one chromosomal fusion/fission resulting in specimens possessing 33 bivalents (homozygotes for fused chromosomes) (Fig. 2b), 32 bivalents +1 trivalents (heterozygotes for fusion/fission) (Fig. 2c, d) and 34 bivalents (homozygotes for unfused chromosomes) (Fig. 2a). Chromosomal rearrangements involved in formation of karyotypes with higher chromosome number $(\mathrm{n}=33-35$ and $\mathrm{n}=34-36)$ remain still unknown. 


\section{P. aserbeidschanus (Fig. 2f-h)}

At the MI/MII stages, the number of chromosome elements was found to vary from $\mathrm{n}=32$ to $\mathrm{n}=37$ in 17 studied specimens from different localities, with $\mathrm{n}=33$ as a modal number. MI/MII metaphases consisted of elements of progressively decreasing size.

\section{P. australorossicus sp. n. (Fig. 2i)}

At the MI/MII stages, the haploid chromosome number $\mathrm{n}=23$ was found in 6 studied individuals. Elements were found to form a gradient size row in which the largest element was approximately 5 times larger than the smallest element. In two specimens, the diploid chromosome number was estimated as $2 n=46$ in male atypical meiosis. In the sample DK-7-97 we counted approximately $\mathrm{n}=$ ca22 and in the sample from Chonkatau we counted approximately $\mathrm{n}=\mathrm{ca} 24$ at the MI stage. The last two counts were done with an approximation due to the overlapping of some bivalents, therefore interpretation of these deviating numbers (a real variation or a mistake of counting) is difficult.

\section{P. damonides damonides from Azerbaijan and Armenia (Fig. 3a-d)}

At the MI/MII stages, the haploid chromosome number $\mathrm{n}=18$ was found in 10 studied individuals. Elements formed a gradient size row in which the largest element was approximately 2-2.5 times larger than the smallest element. In two specimens, the diploid chromosome number was determined as $2 \mathrm{n}=36$ in male atypical meiosis.

\section{P. damonides from Iran (previously known as P. elbursicus) (Fig. 4a-h)}

At the MI/MII stages, the haploid chromosome number $\mathrm{n}=18$ was found in 26 studied individuals. Elements constituted a gradient size row in which the largest element was approximately 2-2.5 times larger than the smallest element. In 7 specimens, the diploid chromosome number was determined as $2 \mathrm{n}=36$ in male atypical meiosis. Thus, the karyotype of these samples from Iran is indistinguishable from the karyotype of the samples of $P$. damonides from Azerbaijan and Armenia.

\section{P. damonides elbursicus (Forster, 1956) (Fig. 5a-e)}

At the MI/MII stages, the haploid chromosome number $\mathrm{n}=17$ was found in four studied individuals. Elements formed a gradient size row in which the largest element was approximately 2-2.5 times larger than the smallest element. In the sample VL311, the diploid chromosome number was determined as $2 n=34$ in male atypical meiosis.

\section{P. damonides gilanensis Eckweiler, 2002 (Fig. 6a-f)}

At the MI/MII stages, the number of chromosome elements was found to vary from $\mathrm{n}=18$ to $\mathrm{n}=19$ in three studied specimens collected in the type-locality of this taxon. Elements formed a gradient size row in which the largest element was approximately 2-2.5 times larger than the smallest element. The population was found to be polymorphic for a chromosomal fusion/fission resulting in specimens possessing 18 bivalents (homozygotes for fused chromosomes), 17 bivalents +1 trivalents (heterozygotes for fusion/fission) (Fig. 6a, b) and 19 bivalents (homozygotes for unfused chromosomes) 


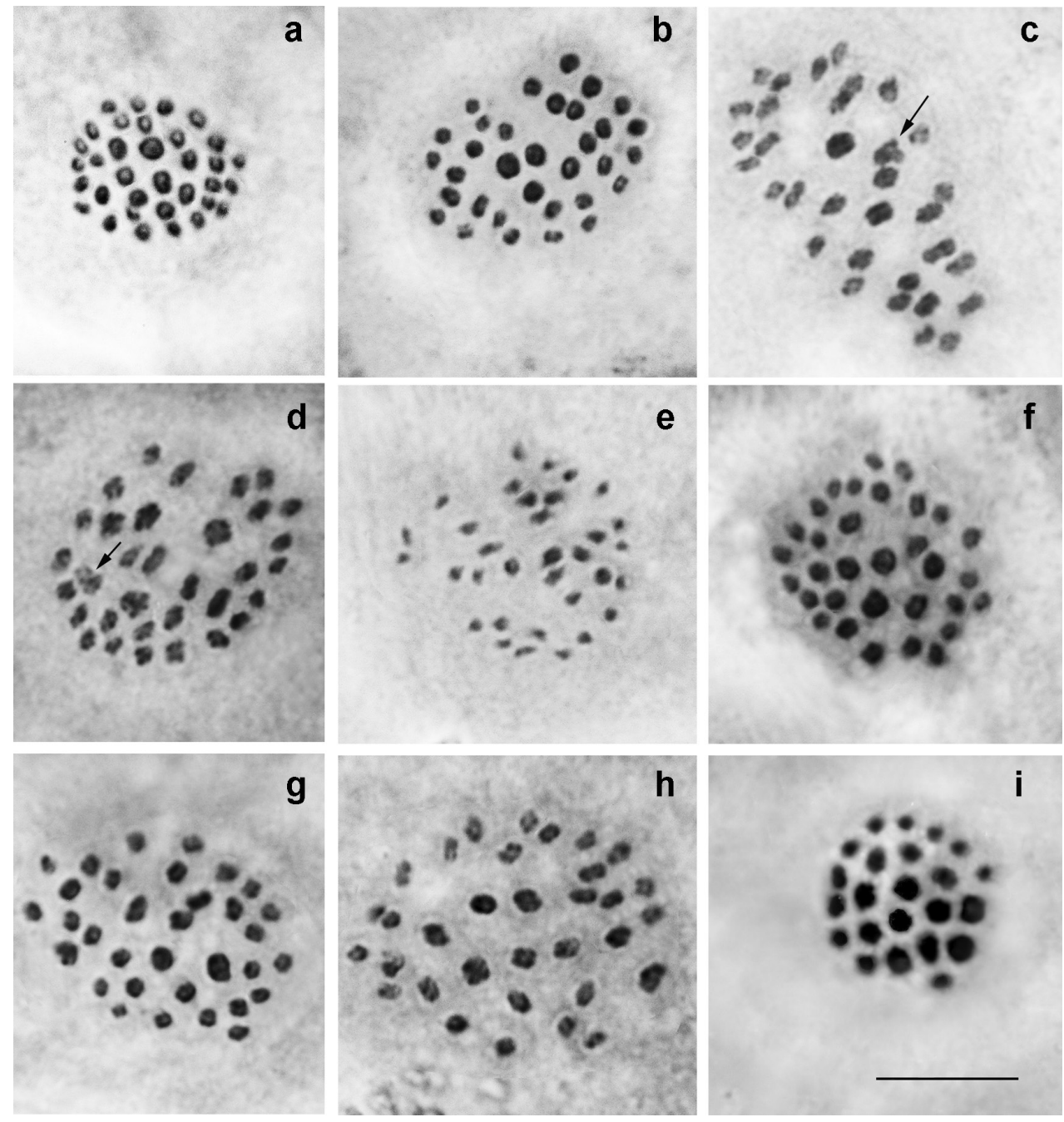

Figure 2. Karyotypes of $P$. ninae, $P$. aserbeidschanus and $P$. australorossicus sp. n. Trivalents are indicated by arrows. a $P$. ninae, sample 2014VL34, MI, $\mathrm{n}=34$ b $P$. ninae, sample 2014VL39, MI, $\mathrm{n}=33$ c $P$. ninae, sample 2014VL33, MI, n=32 bivalents +1 trivalent (heterozygote for fusion/fission) d $P$. ninae, sample 2014VL60, $\mathrm{n}=32$ bivalents +1 trivalent (heterozygote for fusion/fission) e $P$. ninae, sample 2014VL33, MII, $\mathrm{n}=33 \mathbf{f}$ P. aserbeidschanus, sample 05A406, MI, $\mathrm{n}=32 \mathbf{g} P$. aserbeidschanus, sample 05A387, MI, $\mathrm{n}=33$ h $P$. aserbeidschanus, sample 05A387, MI, $\mathrm{n}=33 \mathbf{i}$ P. australorossicus sp. n., sample DK-27-97-1, MI, n=23. Bar $=10 \mu$.

(Fig. 6d-f). Interestingly, in the case of heterozygocity for fusion/fission, the same number of chromosome elements $(\mathrm{n}=18)$ was found at the MI and MII stages, and the trivalent chromosomes (triple chromatids) were observed at both MI and MII stages (Fig. 6a-c). 


\section{P. zarathustra (Fig. 7a)}

At the MI/MII stages, the number of chromosome elements was found to vary from $\mathrm{n}=20-21$ to $\mathrm{n}=24$ in 6 studied specimens from different localities, with $\mathrm{n}=22$ as a modal number. Elements formed a gradient size row in which the largest element was approximately 5 times larger than the smallest element. The species seemed to be polymorphic for several, still unrecognized chromosomal rearrangements resulting in chromosome number variation.

\section{P. arasbarani arasbarani (Fig. $7 \mathrm{~b}$ )}

At the MI/MII stages, the number of chromosome elements was found to vary from $\mathrm{n}=23-24$ to $\mathrm{n}=25$ in 6 studied specimens, most likely due to polymorphism for a single chromosomal fusion/fission. Elements formed a gradient size row in which the largest element was approximately 5-6 times larger than the smallest element.

\section{P. arasbarani neglectus Dantchenko, 2000 (Fig. 7c)}

At the MI stage, the number of chromosome elements was determined to be $\mathrm{n}=25$ in the sample B447. In the samples KA-95-99, 2001-Q456 and 2001-Q457 the number of elements was estimated with an approximation as $n=24-25$ and $n=25-26$ due to the overlapping of some bivalents. In the sample KA-98-99, the diploid chromosome number was estimated as $2 \mathrm{n}=\mathrm{ca} 48$. Elements formed a gradient size row in which the largest element was approximately 5-6 times larger than the smallest element.

\section{P. lukhtanovi (Fig. 7d, e)}

At the MI/MII stages, in 28 of 33 studied specimens the haploid chromosome number was determined as $n=22$. In one of these 28 specimens atypical meiosis displayed $2 n=44$. In 3 of 33 studied samples the haploid chromosome number was determined as $\mathrm{n}=21$, and in two samples intraindividual variation in the number of elements was observed: $n=21-22$. We interpret this result as an evidence for polymorphism for a single fusion/fission resulting in in specimens possessing $n=21$ (Fig. $7 \mathrm{e}$ ) and $\mathrm{n}=21-22$ (homozygotes for fusion and heterozygotes for fusion/fission) and $\mathrm{n}=22$ bivalents (homozygotes for the unfused chromosomes) (Fig. 7). Elements formed a gradient size row in which the largest element was approximately 3 times larger than the smallest element.

\section{P. shamil (Fig. 7f)}

At the MI/MII stages, in all 12 studied specimens the haploid chromosome number was determined as $\mathrm{n}=17$. In three of these 12 specimens atypical meiosis displayed $2 n=34$. Elements formed a gradient size row in which the largest element was approximately 2 times larger than the smallest element. 


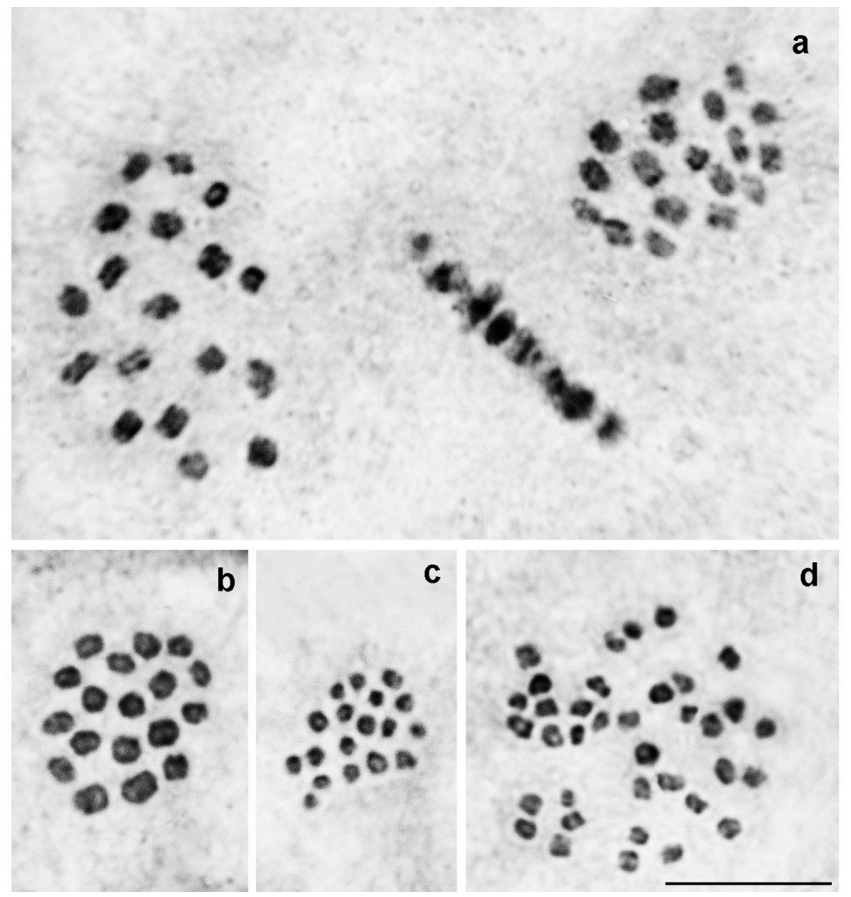

Figure 3. Karyotype of $P$. damonides from Ordubad vicinity in Nakhchivan (Azerbaijan) and Meghri vicinity in Armenia. a sample 005A14K, three MI plates (two from polar view and one from equatorial view) displaying $\mathrm{n}=18$ b sample $005 \mathrm{~A} 14 \mathrm{~K}, \mathrm{MI}, \mathrm{n}=18$ c sample $005 \mathrm{~A} 14 \mathrm{~K}, \mathrm{MII}, \mathrm{n}=18$ d sample 2014VL04, male atypical meiosis, $2 \mathrm{n}=36$. Bar $=10 \mu$.

\section{COI barcode analysis}

The COI barcode analysis revealed three major, highly supported clusters within the studied samples (Fig. 1). The first cluster (haplogroup I) is represented by samples of $P$. ninae, $P$. aserbeidschanus and $P$. australorossicus. This cluster inhabits the northern part of the $P$. damonides complex distribution range: the Russian part of the eastern Caucasus (Daghestan), Georgia, Armenia (except its south-eastern part near Meghri), Nakhchivan in Azerbaijan (except Ordubad district) and north-eastern Turkey (Fig. 8).

Within its distribution range $P$. ninae demonstrates a diversity of $C O I$ haplotypes; however, no distinct intraspecific sublineages were discovered. Polyommatus ninae fruze (Carbonell, 1993) described from Turkey (Gümüşhane, Kelkit) shows no differentiation from topotypical populations from Armenia, and in our opinion should be considered no more than a synonym of $P$. ninae.

The specimens of $P$. aserbeidschanus collected in the type locality of this taxon "Armenia, mts. Zangezur, pag. Kadzharantz, pr. Mts. Kapudzhich" (Forster 1956) were found to share their COI haplotype with the samples of $P$. ninae from Armenia and Azerbaijan. 

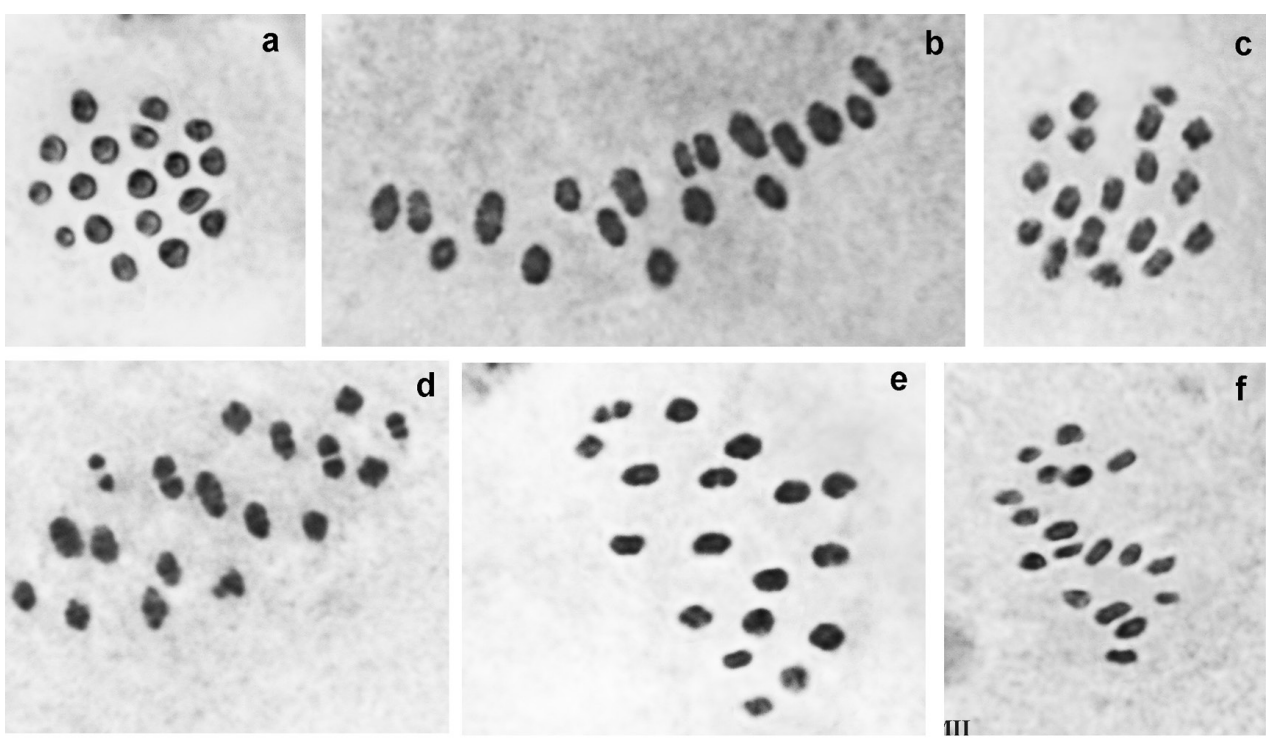

e
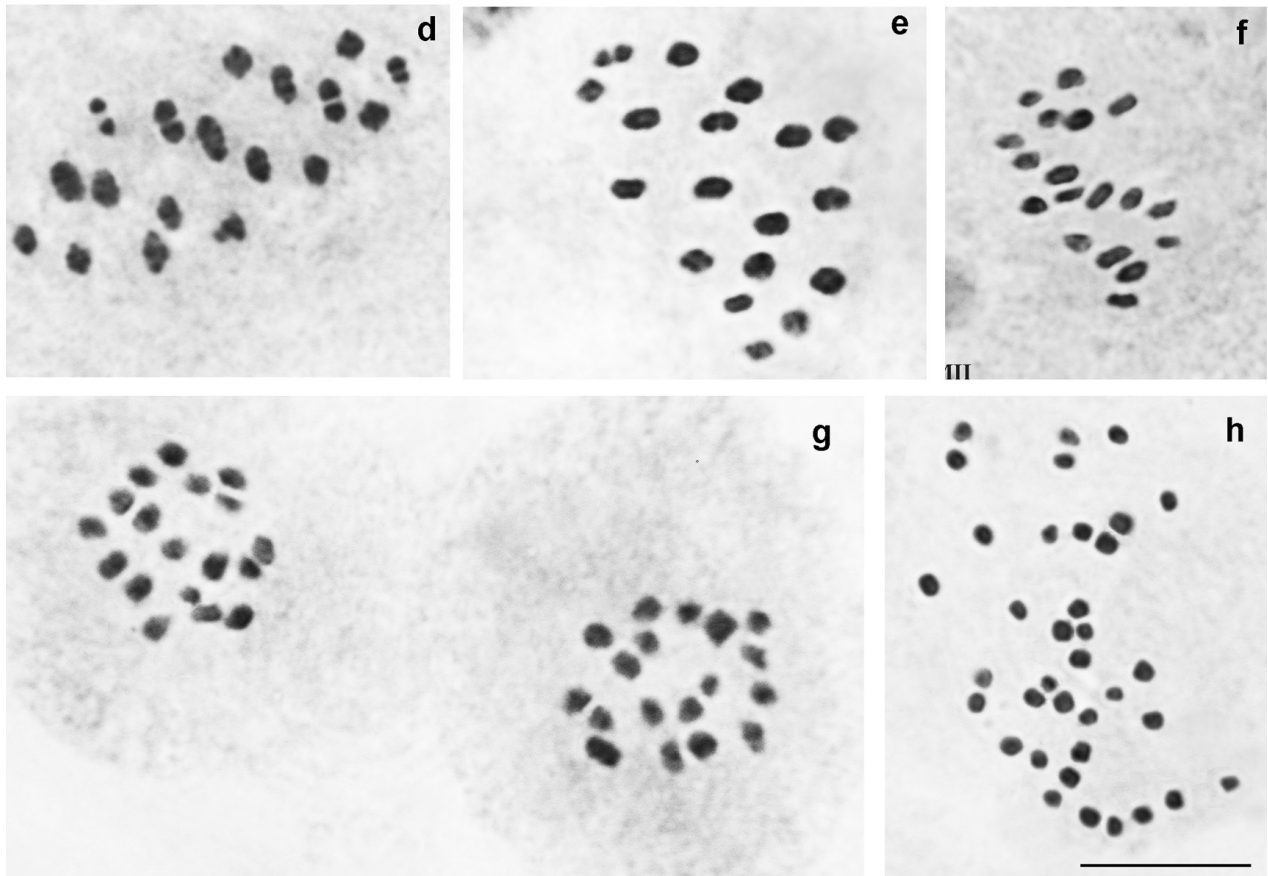

g

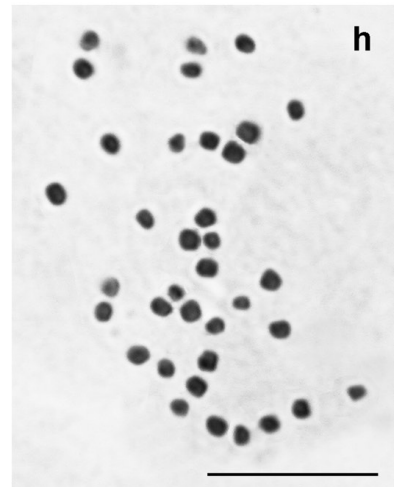

Figure 4. Karyotype of $P$. damonides from Iran (previously known as $P$. elbursicus). a sample E234, MI, $\mathrm{n}=18$ b sample E193, MI, $\mathrm{n}=18$ c sample E460, MI, $\mathrm{n}=18$ d sample E237, MI, $\mathrm{n}=18$ e sample E459, MI, $\mathrm{n}=18 \mathbf{f}$ sample E193, MII, $\mathrm{n}=18 \mathbf{g}$ sample J573, two sister MII plates, $\mathrm{n}=18 \mathbf{h}$ sample E234, male atypical meiosis, $2 \mathrm{n}=36$. Bar $=10 \mu$.

On the tree obtained, the samples of $P$. australorossicus were intermixed together with the samples of $P$. ninae. Although no shared haplotypes were found, the uncorrected $p$-distances between the $P$. ninae and $P$. australorossicus samples were quite low varying from $0.2 \%$ to $1.4 \%$. Thus, both $P$. ninae and $P$. australorossicus appeared on the tree as genetically undifferentiated, non-monophyletic assemblages.

The second lineage (haplogroup II) is represented by samples of $P$. damonides, $P$. elbursicus, $P$. elbursicus gilanensis, $P$. zarathustra, $P$. arasbarani and $P$. lukbtanovi. This is the southern lineage of the $P$. damonides complex distributed in the south-eastern part of Nakhchivan (Ordubad district, Azerbaijan), south-eastern part of Armenia (Meghri district), south-eastern part of Azerbaijan (Talysh) and Iran (Fig. 8). On the tree ob- 


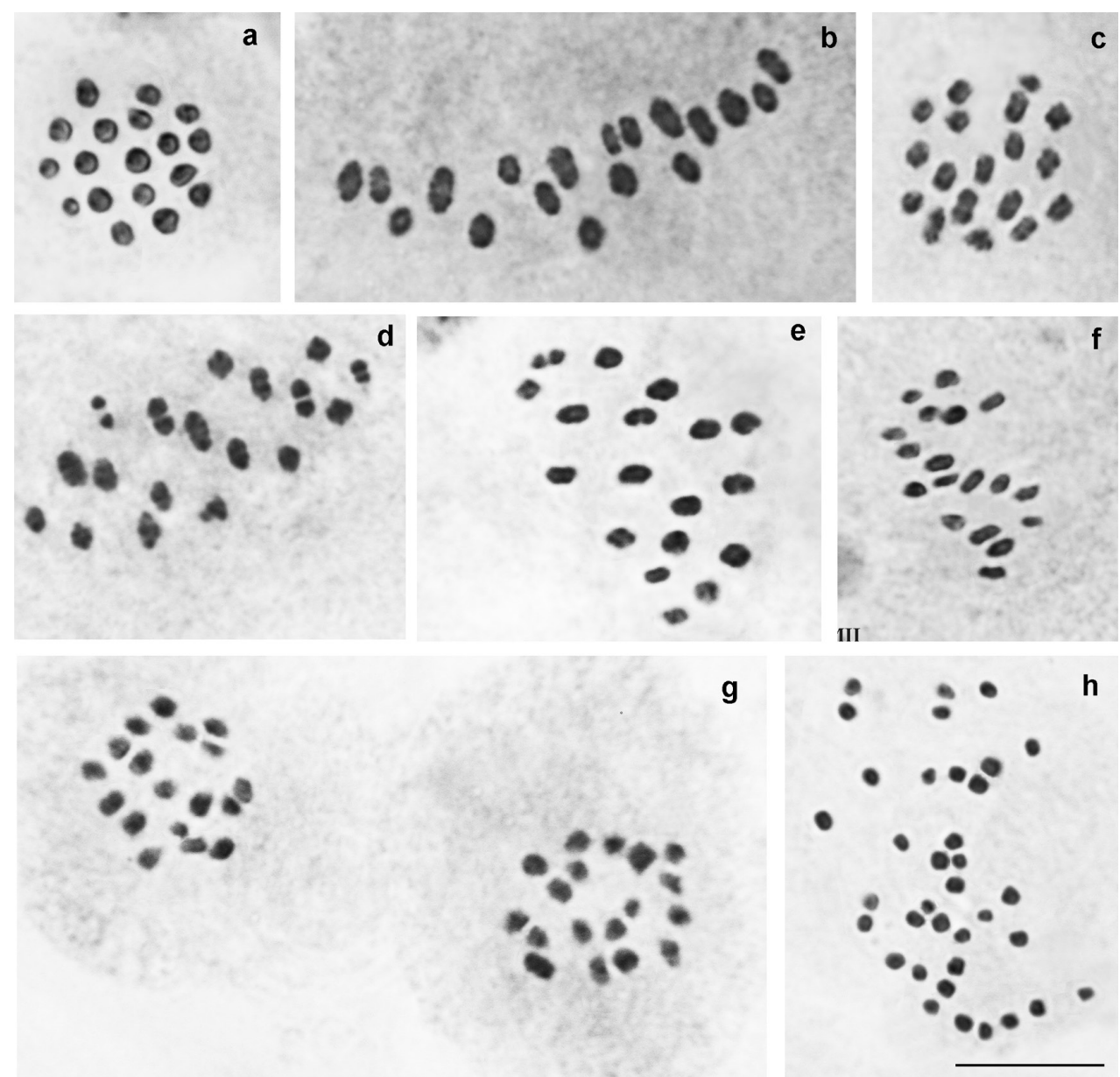

Figure 5. Karyotype of $P$. damonides elbursicus from Elburs Mts (north Iran). a sample M804, MI, n=17 b sample VL302, two MI plates, each displaying n=17 c sample VL302, diakinesis - early prometaphase, $\mathrm{n}=17 \mathbf{d}$ sample VL302, prometaphase, $\mathrm{n}=17$ e sample VL302, MII, $\mathrm{n}=17$. Bar $=10 \mu$.

tained, the samples of this lineage were deeply intermixed, and all these taxa appeared as undifferentiated non-monophyletic assemblages.

The third lineage (haplogroup III) (south-western group) is represented by samples of $P$. pierceae. This lineage inhabits the south-eastern part of Turkey (Fig. 8).

\section{Discussion}

\section{Rapid chromosomal evolution and possibility of chromosomal speciation}

The $P$. damonides species complex demonstrates a high rate of karyotype evolution resulting in a great interspecific diversity of chromosome numbers (from $n=17$ to $n$ 34- 


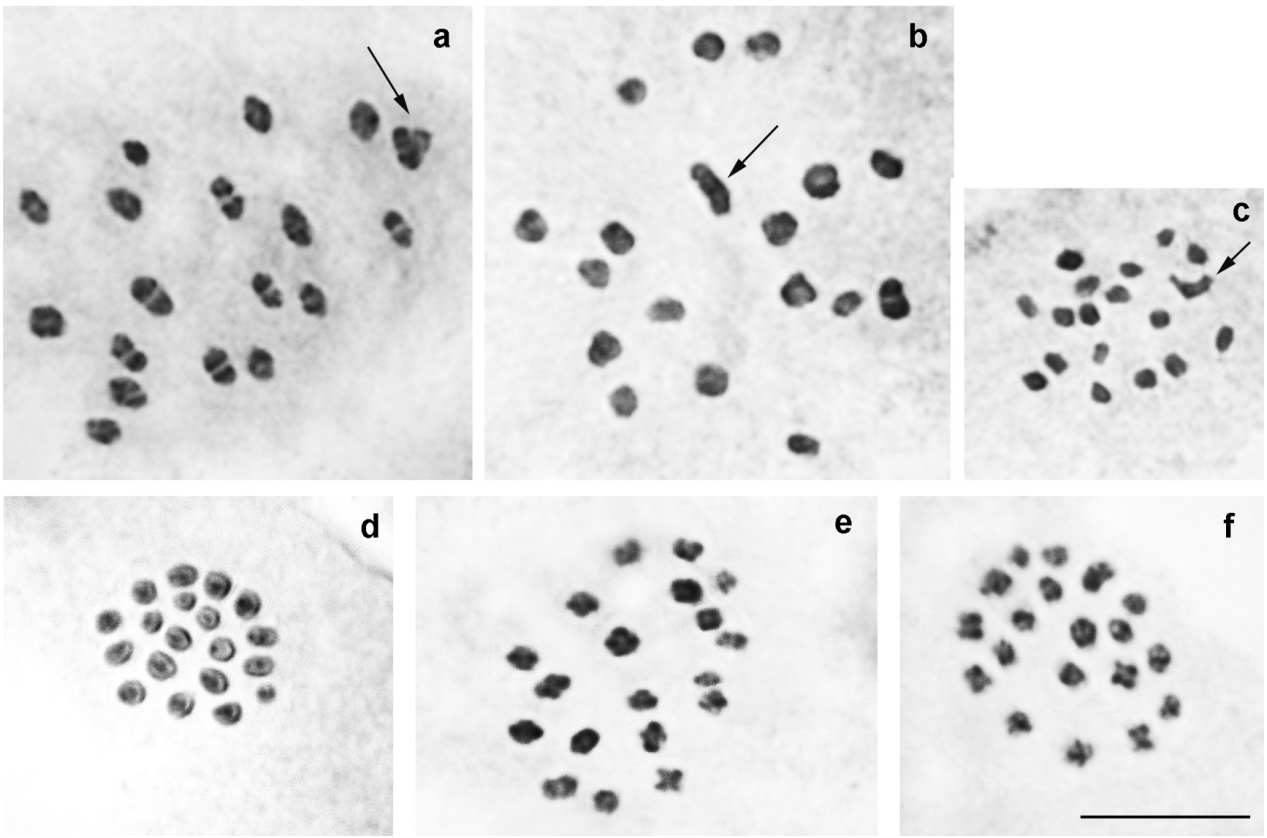

Figure 6. Karyotype of $P$. damonides gilanensis from its type-locality. Trivalents and triple chromatid are indicated by arrows. a sample J111, MI, $\mathrm{n}=18$ b sample J111, MI, $\mathrm{n}=18$ c sample J111, MII, $\mathrm{n}=18$ d sample J112, MI, n=19 e sample J112, MI, $\mathrm{n}=19$ f sample J112, MI, $\mathrm{n}=19$. Bar $=10 \mu$.

36) (Figs 2-7) despite the low (between the haplogroups I and II) or lack of (within the haplogroups I and II) (Fig. 1) COI differentiation. Fusions and fissions of chromosomes are the most probable rearrangements driving the chromosome number change in the $P$. damonides complex as well as in other butterfly species (Lukhtanov et al. 2011, Šíchová et al. 2015, 2016). In $P$. ninae, $P$. damonides gilanensis, $P$. arasbarani and $P$. lukhtanovi some of these fusions/fissions are found in heterozygous conditions resulting in trivalent formation at the MI stage.

There are two possible ways of the first meiotic division in a cell with the fusion/fission trivalent: (i) resulting in a daughter cell containing two smaller chromosomes and a daughter cell containing one larger chromosome, and (ii) resulting in two daughter cells, each containing an element consisting of three triple chromatids (Nokkala et al. 2006). In case of chiasmate meiosis, Nokkala et al. (2006) interpreted both ways as two different variants of conventional pre-reductional meiosis, whereas Banno et al. (1995) interpreted the second way as post-reductional meiosis. The latter is also known as "inverted meiosis" (see e.g. Heckman et al. 2014, Manicardi et al. 2015, Bogdanov 2016). Despite the difference in the interpretation (in fact despite the difference in the definition of conventional and inverted meiosis), both papers stress the significant distinction between the first and the second ways. In P. damonides gilanensis the trivalent- 

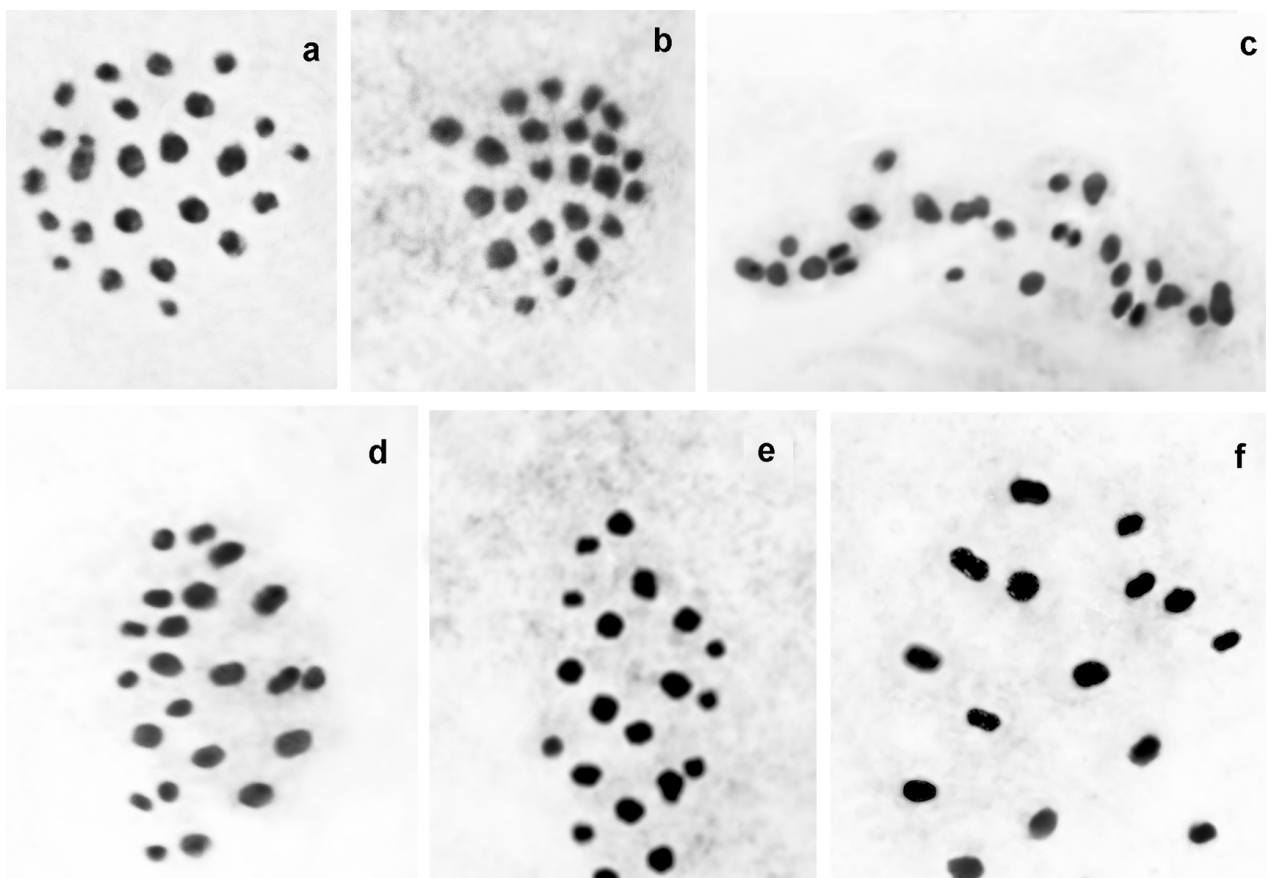

\section{d}

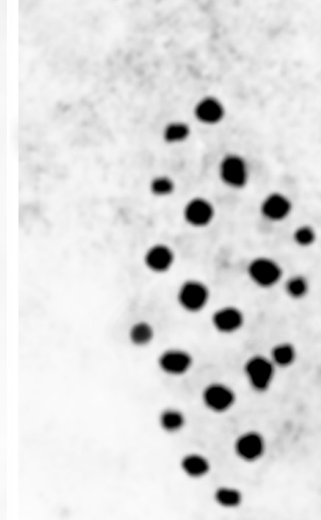

e

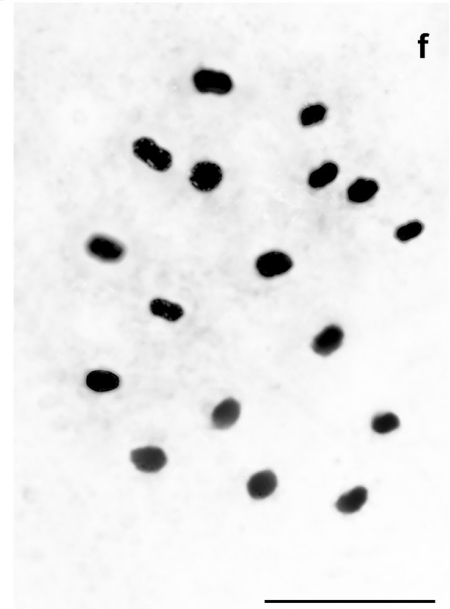

Figure 7. Karyotypes of $P$. zarathustra, $P$. arasbarani, $P$. lukbtanovi and $P$. shamil. a $P$. zarathustra, sample Z401, MI, n=24 b $P$. arasbarani arasbarani, sample N98, MI, n=24 c $P$. arasbarani neglectus, sample Q457, MI, $\mathrm{n}=\mathrm{ca} 25-26 \mathbf{d} P$. lukhtanovi, sample F875, MI, $\mathrm{n}=22$ e $P$. lukhtanovi, sample H717, MI, $\mathrm{n}=21$ f $P$. shamil, sample F958, MI, $\mathrm{n}=17$. Bar $=10 \mu$.

similar elements were found not only at the MI (Fig. 6a, b), but also at the MII stage (Fig. 6c), most likely due to the second way of the first meiotic division.

The fact that the discovered fusions/fissions can exist in populations in both homoand heterozygous conditions indicates, most likely, that these rearrangements can pass through meiosis and are not strongly underdominant. Previously, the low or no underdominance of chromosomal fusions/fissions was demonstrated for butterflies of the genus Leptidea Billberg, 1820 (Lukhtanov et al. 2011, Šíchová et al. 2015, 2016). In the Agrodiaetus subgenus the low underdominance of chromosomal fusions/fissions was indirectly demonstrated through analysis of homoploid hybrid speciation in $P$. karindus-P. morgani-P. peilei species complex (Lukhtanov et al. 2015b). Particularly, the formation of the diploid hybrid species P. peilei Bethune-Baker, 1921 had to include a hybrid ancestor heterozygous for at least 41 single chromosome fusions/fis- 


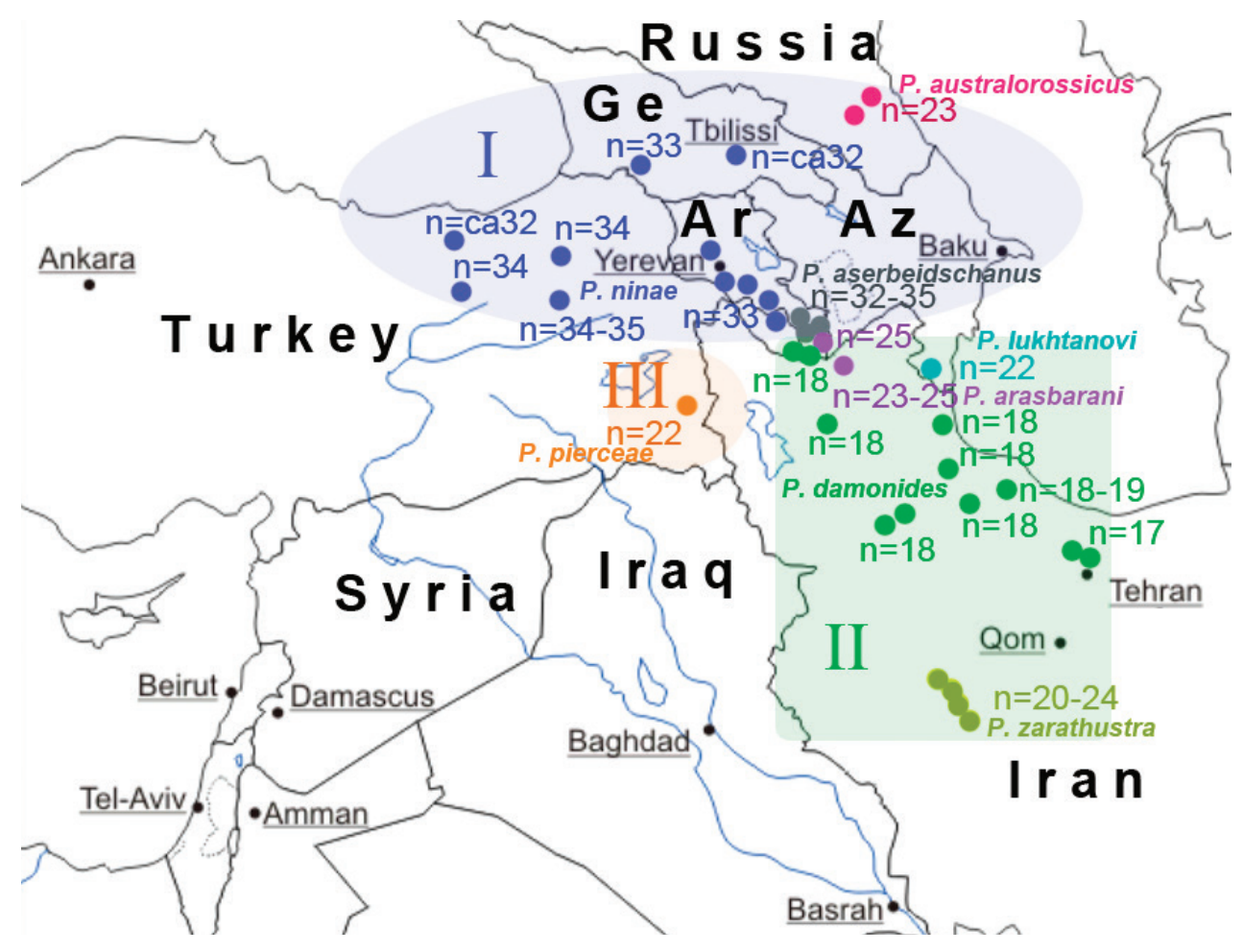

Figure 8. Distribution of COI haplogroups (I - III) and haploid chromosome numbers (n) in the $P$. damonides species complex.

sions, and this ancestor was at least partially fertile (Lukhtanov et al. 2015b). The low underdominance of the chromosomal fusions/fissions does not mean that these rearrangements are unimportant for the formation of reproductive isolation and speciation. The accumulation of multiple fusions/fissions can reduce gene flow between chromosomally divergent populations not only via (i) the hybrid-sterility mechanism (when chromosomal rearrangements reduce fertility of chromosomal heterozygotes), but also via (ii) the suppressed-recombination mechanism (even if chromosomal rearrangements are neutral and do not influence fertility of chromosomal heterozygotes) (Faria and Navarro 2010). Comparative phylogenetic analyses demonstrates that the second mechanism is more probable in Agrodiaetus (Vershinina and Lukhtanov 2017), and the gradual accumulation of chromosomal fusions-fissions can certainly drive speciation (Lukhtanov et al. 2005, Kandul et al. 2007).

Thus, the fixed differences in karyotype are not only (syn)apomorphic characters demonstrating that chromosomal races represents distinct phylogenetic lineages, i.e. species from the point of view of phylogenetic species concepts, but also indirect evidence for at least partial reproductive isolation. 


\section{COI differentiation and taxonomy of the $P$. damonides complex}

The studied complex demonstrates a high level of chromosomal differentiation between taxa and a relatively low level of differentiation with respect to the mitochondrial COI gene, with many distinct taxa intermixed on the COI tree obtained (Fig. 1). This result is quite expected taking into account the previous studies (Wiemers 2003, Kandul et al. 2004, Wiemers and Fiedler 2007, Lukhtanov and Shapoval 2017) that demonstrated low interspecific differenciation and even the presence of shared COI barcodes between several distinct species of Agrodiaetus. For chromosomally divergent species, such a situation can be explained by (i) a high rate of diversification in Agrodiaetus resulting in numerous young species sharing ancestral polymorphism for $C O I$ and/or (ii) occasional interspecific hybridization resulting in mitochondrial introgression (Kandul et al. 2004, Lukhtanov et al. 2005, Vishnevskaya et al. 2016). For example, both explanations can be applied to explain the molecular relationship between chromosomally divergent $P$. ninae and $P$. australorossicus, although the second explanation (mitochondrial introgression) seems to be much less probable given the current geographic isolation between them (Fig. 8).

In case of the pair $P$. ninae $-P$. aserbeidschanus which are indistinguishable in both molecular and chromosomal characters, we can also hypothesize that these two nominal taxa are conspecific. These two taxa have been long time considered as distinct species because of a wrong assumption about their karyotypic differentiation (Lukhtanov 1989). However, the analysis of karyotype of $P$. ninae from its type-locality (Armenia: vicinity of Azizbekov, now Vaik) (Lukhtanov 1989) and of $P$. aserbeidschanus from its type-locality (Armenia: vicinity of Kadzharan, now Kajaran) (this study) did not reveal any differences between them, and the molecular analysis demonstrated the identity of their COI barcodes (although nuclear genes have not been studied yet).

However, $P$. ninae and $P$. aserbeidschanus are not identical with respect to their morphology and ecological preferences. Male specimens of P. aserbeidschanus (mostly collected around the type locality in South Zangezur Range) have specific dark brown coloration on the wing underside, blue ground color with violet tint on the wing upperside and significantly smaller size compared with the males of $P$. ninae. Polyommatus aserbeidschanus is known only from the subalpine belt of the South Zangezur mountain area and connected trophically with the Astragalus species preliminary determined as Astragalus prilipkoanus (sectio Incani) (Fabaceae) (Dantchenko 2010). As it was shown previously, Astragalus species of the sectio Incani are also host plants for other taxa of the $P$. (A.) damonides species group (Dantchenko 2010). Typical males of $P$. ninae are larger in size and have blue (not violet) coloration of the upper surface of the wings. Typical $P$. ninae inhabits tragacanth communities in the Vayots Dzor mountain range and its hostplant is Astragalus montis-aquilis (sectio Incani) (Dantchenko 2010). Despite this morphological and ecological differentiation, $P$. ninae and $P$. aserbeidschanus can be theoretically interpreted as local intraspecific forms of the same species, and further studies are required to clarify this situation.

A similar case is found in the pair $P$. zarathustra $-P$. arasbarani. These two taxa are allopatric, and similar with respect to morphology, karyotypes and COI barcodes. 
However, they are differentiated with respect to ecological preferences: P. zarathustra is associated with dry areas in central Iran, whereas $P$. arasbarani is associated with meadow-like biotopes in subalpine zone of the north-west Iran. Polyommatus arasbarani neglectus is known only from low and middle altitude on southern slopes of the Meghri mountain range, it inhibits dry glades and clearance in an oak forest belt and trophically connected with astragalus species preliminary determined as Astragalus fedorovi (sectio Incani) (Fabaceae). This ecological differentiation does not allow synonymaizing these taxa, and further studies are required to clarify this situation, too.

Lycaena Damone var. Damonides Staudinger, 1899 is the oldest taxon described within the studied complex. Therefore analysis of its identity is of great importance for solving nomenclatural problems within the group. The taxon was described as a form of Polyommatus damone (hypothesis 1 ) and later considered as an entity close to P. poseidon (Forster 1961) (hypothesis 2), to P. ninae (Hesselbarth et al. 1995, p. 735, Eckweiler and Bozano 2016) (hypothesis 3) or to P. elbursicus (Lukhtanov in Hesselbarth et al. 1995, p. 735) (hypothesis 4) (see also Olivier et al. 1999, p. 16). Here we have analyzed the karyotype and COI barcodes of the samples from the type-locality (Ordubad in Nakhchivan, Azerbaijan) as well as the samples from the neighboring territory of Armenia (Meghri). Based on this material, we demonstrate that the hypothesis 4 is true. Thus, $P$. damonides appears as a taxon close and most likely conspecific with the taxon previously known as $P$. elbursicus. Therefore, we propose a taxonomic rearrangement of this group and suggest the following new combinations: $P$. damonides elbursicus Forster, 1956, comb. n. and P. damonides gilanensis Eckweiler, 2002, comb. n.

According to our observations $P$. damonides damonides inhabits tragacanth and Paliurus plant communities from $1000 \mathrm{~m}$. alt. (in Armenia) to $2100 \mathrm{~m}$. alt. (in Nakhchivan, vicinity of Ordubad) and is trophically connected with Astragalus ordubadensis (sectio Incani) (Fabaceae) which is endemic of South Zangezur mountain range. It is also important to note that in Meghri-Ordubad region we have found sympatry/ syntopy for the species pairs $P$. arasbarani neglectus/P.damonides damonides, $P$. arasbarani neglectus/P. aserbeidschanus and $P$. damonides/ P. aserbeidschanus.

\section{New species description}

Polommatus (Agrodiaetus) australorossicus sp. $\mathbf{n}$. http://zoobank.org/12D80F81-ECEB-4888-B148-A0D6AD3B8BC1

Holotype (Fig. 9a, b), male, BOLD process ID BPAL2013-13, field \# CCDB-17947_ B06, GenBank accession number MG243366; karyotype preparation DK-27-97, n=23; Russia, Caucasus, Daghestan, Gimrinsky Range, Gunib, $42.406274^{\circ} \mathrm{N}, 46.931548^{\circ} \mathrm{E}$, 1680 m, 14 August 1997, A. Dantchenko leg., deposited in the Zoological Institute of the Russian Academy of Science (St. Petersburg).

COI barcode sequence of the holotype (BOLD process ID BPAL2013-13; GenBank accession number MG243366). 
ACATTATATTTTATTTTTGGAATTTGAGCAGGAATAGTAGGAACATCCNTAAGAATTTTAATTCGTATAGAATTGAGAACTCCTGGATCCTTAATTGGAGATGATCAAATTTATAACACTATTGTTACAGCTCATGCATTTATTATAATTTTTTTTATAGTTATACCTATTATAATCGGAGGATTTGGTAACTGATTAGTTCCTTTAATATTAGGGGCACCTGATATAGCCTTTCCACGACTAAATAATATAAGATTCTGATTATTACCGCCATCATTAATACTACTAATTTCCAGAAGAATTGTAGAAAATGGAGCAGGAACAGGATGAACAGTTTACCCCCCACTTTCATCTAATATTGCACATAGAGGATCATCTGTAGATTTAGCAATTTTCTCTCTTCATTTAGCAGGAATTTCTTCAATTTTAGGAGCAATTAATTTTATTACAACTATTATTAATATACGGGTAAATAATTTATCTTTTGATCAAATATCATTATTTATTTGAGCAGTGGGAATTACAGCATTATTATTACTTTTATCTTTACCTGTATTAGCTGGAGCAATTACCATATTATTAACTGATCGAAATCTTAACACCTCATTCTTTGATCCAGCTGGTGGAGGAGATCCAATTTTATATCAACATTTA

Paratypes. 9 males. (1) BOLD process ID BPAL2011-13, field \# CCDB-17947_ B04; karyotype preparation DK-34-1-97; Russia, Caucasus, Daghestan, Gimrinsky Range, Gunib, 1800 m, 15 August 1997, A. Dantchenko leg. (2) BOLD process ID BPAL2012-13, field \# CCDB-17947_B05; karyotype preparation DK-34-2-97, n=ca23; Russia, Caucasus, Daghestan, Gimrinsky Range, Gunib, 1800 m, 15 August 1997, A. Dantchenko leg. (3) BOLD process ID BPAL2014-13, field \# CCDB17947_B07; karyotype preparation DK-7-97, n=ca22; Russia, Caucasus, Daghestan, Gimrinsky Range, Gunib, 1800 m, 12 August 1997, A. Dantchenko leg. (4) karyotype preparation DK-23-97, n=23, 2n=46; Russia, Caucasus, Daghestan, Gimrinsky Range, Gunib, 1800 m, 15 August 1997, A. Dantchenko leg. (5) karyotype preparation DK-30-97, n=23; Russia, Caucasus, Daghestan, Gimrinsky Range, Gunib, 1800 m, 15 August 1997, A. Dantchenko leg. (6) karyotype preparation DK-23-97-3, n=23; Russia, Caucasus, Daghestan, Gimrinsky Range, Gunib, 1800 m, 14 August 1997, A. Dantchenko leg. (7) karyotype preparation DK-23-97-4, 2n=ca46; Russia, Caucasus, Daghestan, Gimrinsky Range, Gunib, 1800 m, 14 August 1997, A. Dantchenko leg. (8) karyotype preparation DK-27-97-2, n=23; Russia, Caucasus, Daghestan, Gimrinsky Range, Gunib, 1800 m, 14 August 1997, A. Dantchenko leg. (9) karyotype preparation n=?24; Russia, Caucasus, Daghestan, Chonkatau, V. Tikhonov leg. All paratypes are deposited in the Zoological Institute of the Russian Academy of Science (St. Petersburg).

Additional samples (no DNA, no karyotype). 10 males: Russia, Caucasus, Daghestan, Gimrinsky Range, Gunib, 1450-1950 m, 11-16 August 1997, A. Dantchenko leg.

Males. Forewing length 16.5-18.5 mm.

Upperside: Ground colour bright glossy violet blue with narrow black marginal line, marginal part of forewings and hindwings slightly dusted with black scales, discal strokes absent, veins darkened distally, costal area of the forewings white, basal part of fringe dark grey on forewings, light grey on hindwings, distal part white.

Underside: Forewing ground colour grey, submarginal row blurred, but clear visible; discoidal strokes black, bordered with white; postdiscal rows of black spots bor- 


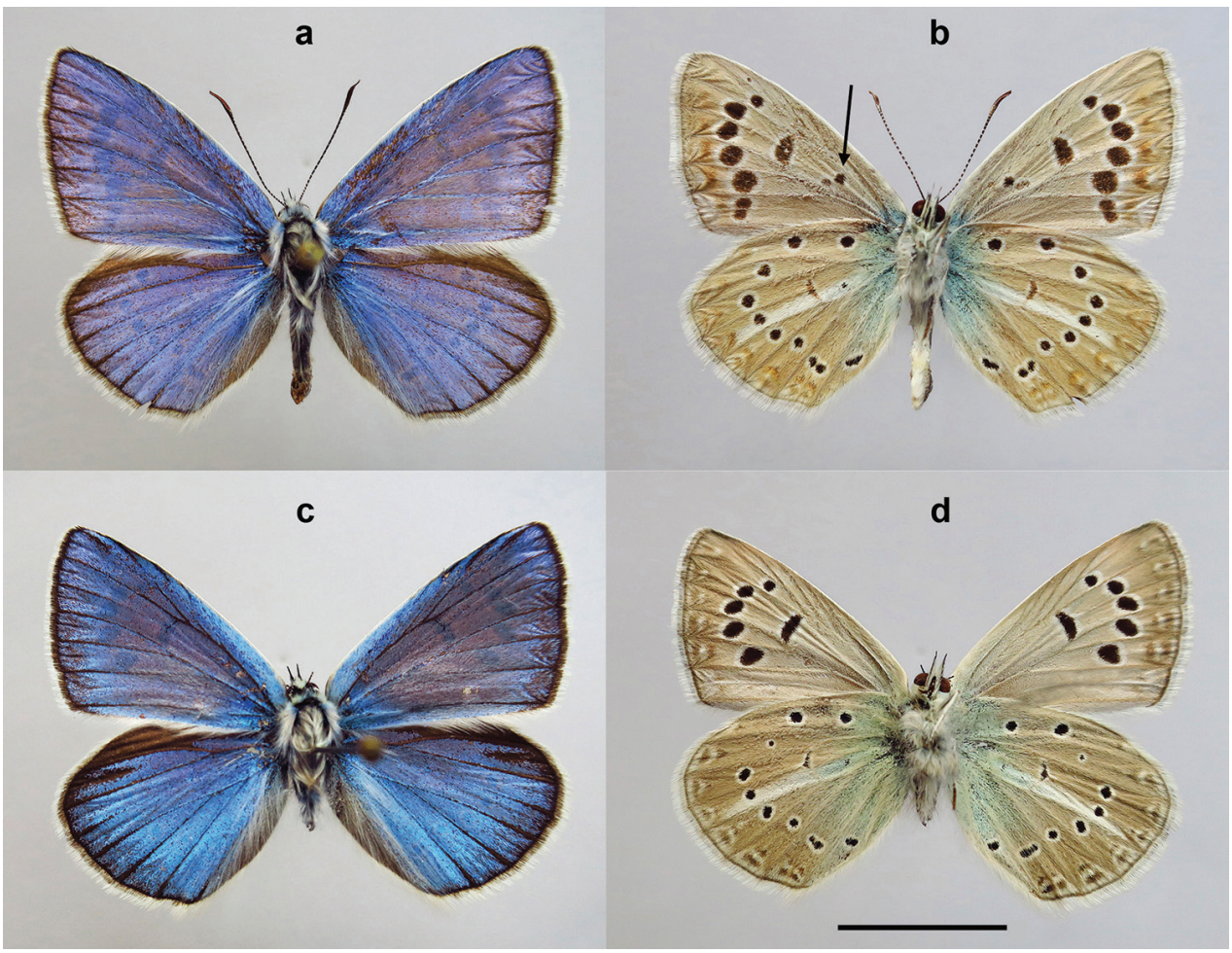

Figure 9. Specimens of Polyommatus (Agrodiaetus) australorossicus sp. n. and P. (A.) shamil. Both samples collected in Gunib (Russia, Caucasus, Daghestan, Gimrinsky Range, 1600-1800 m), 14 August 1997, by A. Dantchenko. a, b upperside (a) and underside (b) of the holotype of Polyommatus (Agrodiaetus) australorossicus sp. $\mathrm{n}$. DK-27-97, $\mathrm{n}=23$; arrow indicates basal black spot $\mathbf{c}, \mathbf{d}$ upperside (c) and underside (b) of the paratype of Polyommatus (Agrodiaetus) shamil, CCDB-17947_B11, DK-97-18, $\mathrm{n}=17,2 \mathrm{n}=34$. Bar $=10 \mathrm{~mm}$.

dered with white, $80 \%$ males have basal black spots; hindwing ground colour grey with ocherous tint, basal area with strong greenish suffusion; discal stroke less prominent than on forewings; postdiscal row of black spots bordered with white, submarginal and antemarginal marking not strong but clear visible; submarginal row bordered distally with reddish brackets, more pronounced to anal end of row; white streak sharp, equal in width; basal half of fringes pale grayish on fore- and hindwings, distal part white.

Females remains unknown.

Genitalia. The male genitalia have a structure typical for other species of the subgenus Agrodiaetus (Coutsis 1986).

Habitat and biology. Stony steppe and dry meadows from 1500 up to $2000 \mathrm{~m}$ a.s.l. Flight period: mid-July to end of August, in a single generation. The new species flights syntopically and synchronously with $P$. shamil but on average about one decade earlier. Host plant is preliminary determined as Astragalus buschiorum (Fabaceae). Hibernation as first instar larvae. 

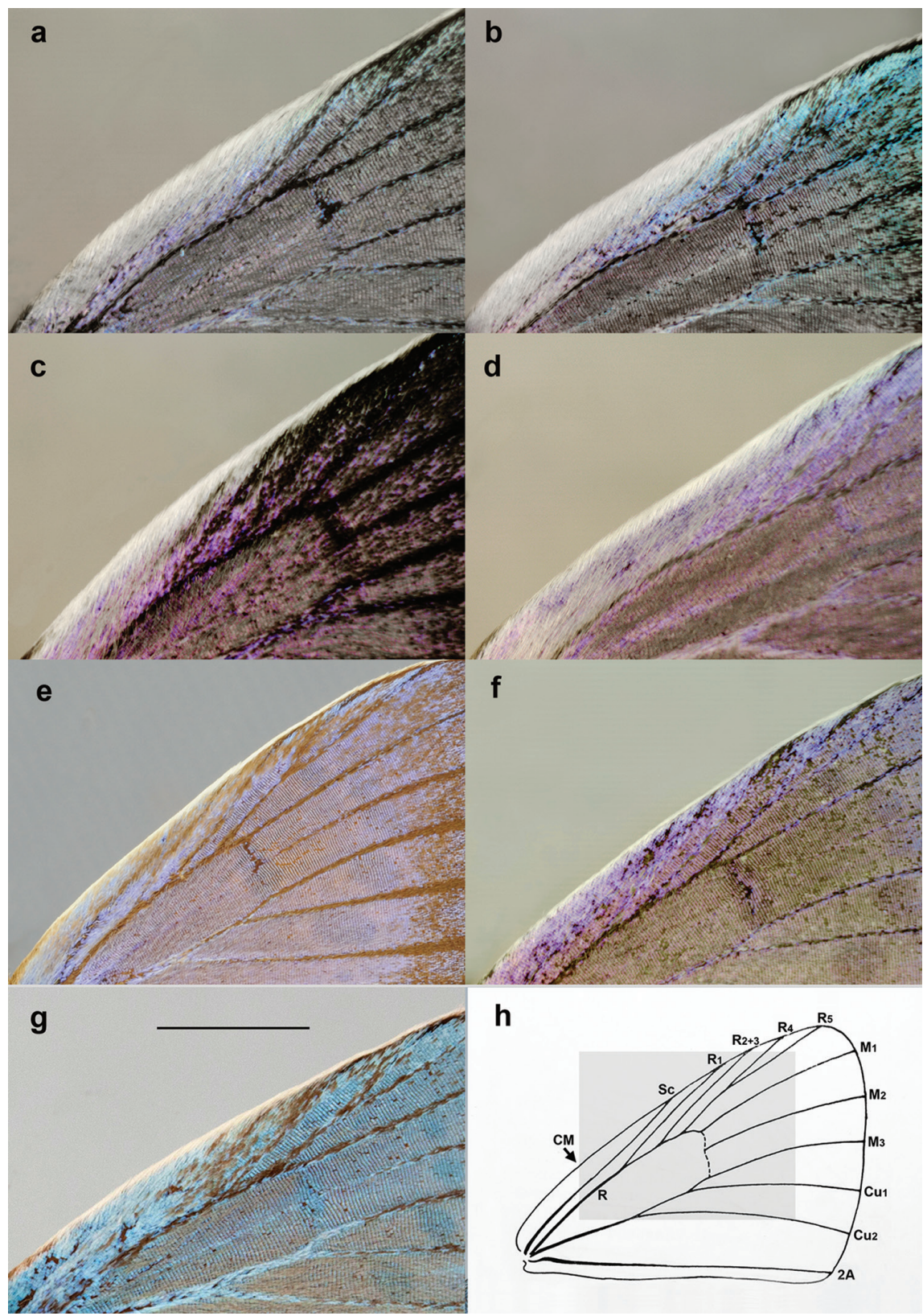

h

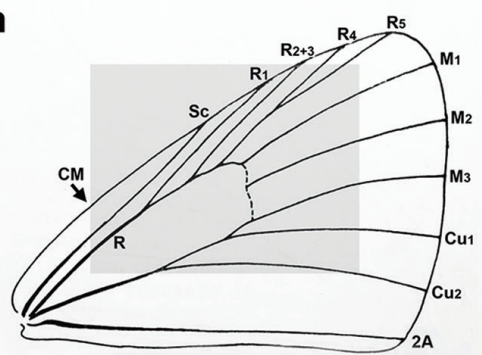

Figure 10. Pubescence of the anterior part of the forewing upper surface. a, b, c, $\mathbf{d}$ the anterior part of the forewing upper surface possesses a strong white pubescence in the area bordered by the costal margin $(\mathrm{CM})$ and the veins $\mathrm{R}$ and $\mathrm{R}_{2+3}$, i.e. this area is densely covered with relatively long white hairs (a $P$. aserbeidschanus $\mathbf{b}$ P. ninae, $\mathbf{c}$. arasbarani neglectus $\mathbf{d} P$. australorossicus) $\mathbf{e}, \mathbf{f}$ the white pubescence of the anterior part of the forewing upper surface is strongly reduced and limited to the only costal margin, the white hairs are short (e P. ciscaucasicus $\mathbf{f}$ P. shamil) $\mathbf{g}$ the white pubescence of the anterior part of the forewing upper surface is reduced, not dense (P. damonides) $\mathbf{h}$ schematic picture showing the venation of the forewing in Polyommatus and the photographed area (shaded). Bar $=3 \mathrm{~mm}$. 
Diagnosis. Phenotypically $P$. (A.) australorossicus sp. $\mathrm{n}$. is practically indistinguishable from allopatric closely related $P$. ninae, $P$. aserbeidschanus and $P$. lukhtanovi but the ground colour of the underside of the hindwings is grey in the new species, with ocherous tint, not light or dark brown. The new species differs from sympatric (syntopic and synchronous) P. shamil (Fig. 9c, d) by specific structure of costal area of the forewings in males (Fig. 10). The submarginal row of spots on the forewing underside is more blurred (Fig. 9b), not sharp and clear visible as in P. shamil (Fig. 9d). Additionally, basal black spots are usually present on the underside of the forewings in $P$. (A.) australorossicus (Fig. 9b); however, this character is not constant.

Genetically $P$. australorossicus and $P$. shamil are not close. They belong to two different species groups within the subgenus Agrodiaetus: to $P$. carmon group (P. australorossicus) and to $P$. cyaneus group (P. shamil).

The new species differs drastically from the genetically most closely related $P$. ninae and $P$. aserbeidschanus by its karyotype (by at least 9 fixed chromosomal fusions/fissions).

The new species is similar (but not identical) to P. lukhtanovi $(\mathrm{n}=21-22)$ and $P$. pierceae $(\mathrm{n}=22)$ with respect to the chromosome number. However, it differs from these species by COI barcodes and represents a different lineage of evolution within the $P$. damonides complex.

Etymology. The name australorossicus is an adjective of the masculine gender. This species name originates from the Latin words "australis" (south) and "rossicus" (Russian).

\section{Taxonomic conclusion}

We propose the following taxonomic arrangement of the $P$. damonides species complex (chromosome numbers are in parentheses):

\section{i. Polyommatus (Agrodiaetus) ninae lineage}

P. (A.) ninae (Forster, 1956) (Agrodiaetus transcaspica ninae Forster, 1956; =Agrodiaetus ninae firuze Carbonell, 1993) ( $\mathrm{n}=33-35)$

P. (A.) aserbeidschanus (Forster, 1956) (Agrodiaetus transcaspica aserbeidschana Forster, 1956) $(\mathrm{n}=32-37)$

P. (A.) australorossicus, sp. $\mathrm{n} .(\mathrm{n}=23)$

\section{ii. Polyommatus (Agrodiaetus) damonides lineage}

$P$. (A.). damonides (Staudinger,1899)

P. (A.) damonides damonides (Staudinger, 1899) (Lycaena Damone var. Damonides Staudinger, 1899) $(\mathrm{n}=18)$

P. (A.) damonides elbursicus (Forster, 1956), comb. n. (Agrodiaetus transcaspica elbursica Forster, 1956) ( $\mathrm{n}=17)$

P. (A.) damonides gilanensis Eckweiler, 2002, comb. n. (Polyommatus (Agrodiaetus) elbursicus gilanensis Eckweiler, 2002) $(\mathrm{n}=18-19)$ 
P. (A.) lukhtanovi (Dantchenko, 2005) (Agrodiaetus lukhtanovi Dantchenko, 2005) $(\mathrm{n}=21-22)$

P. (A.) zarathustra Eckweiler, 1997 (Polyommatus (Agrodiaetus) zarathustra Eckweiler, 1997) $(\mathrm{n}=20-24)$

P. (A.) arasbarani (Carbonel \& Naderi, 2000)

P. (A.) arasbarani arasbarani Carbonel \& Naderi, 2000 (Agrodiaetus arasbarani Carbonel \& Naderi, 2000) $(\mathrm{n}=24-25)$

P. (A.) arasbarani neglectus Dantchenko, 2000 (Polyommatus (Agrodiaetus) zarathustra neglectus Dantchenko, 2000; = Polyommatus (Agrodiaetus) arasbarani ihmal Koçak \& Kemal, 2008) ( $\mathrm{n}=24-26)$

\section{iii. Polyommatus (Agrodiaetus) pierceae lineage}

P. (A.) pierceae (Lukhtanov \& Dantchenko, 2002) (Agrodiaetus pierceae Lukhtanov \& Dantchenko, 2002) (n=22)

Comment. The name Polyommatus (Agrodiaetus) arasbarani ihmal was suggested by Koçak and Kemal (2008) to replace Polyommatus (Agrodiaetus) zarathustra neglectus Dantchenko, 2000. Koçak and Kemal (2008) assumed that Polyommatus (Agrodiaetus) zarathustra neglectus Dantchenko, 2000 was a junior homonym of Polyommatus neglectus Stradomsky \& Arzanov [2000], a species close to Polyommatus icarus (Rottemburg, 1775) described by Stradomsky and Arzanov in the second issue of the volume 7 of Izvestiya Kharkovskogo Entomologicheskogo Obschestva (p. 19) (Stradomsky and Arzanov [2000]). This issue is dated by the year 2000; however, the real date is not clear. As is written on the page 172 the issue was signed for printing on December 21, 1999, but the day when it was really printed and became accessible is unknown. This issue appeared in the library of the Zoological Institute of the Russsian Academy of Science on July 18, 2000. Thus we assume that it was published between December 21, 1999 and July 18, 2000.

The volume 48 of Neue Entomologische Nachrichten with description of Polyommatus (Agrodiaetus) zarathustra neglectus Dantchenko, 2000 was published and distributed in May 2000. Additional studies are required to clarify what taxon (described by Dantchenko or described by Stradomsky and Arzanov) was published first. Until this situation is resolved in a future revision, we see no other way than to use $P$. (A.) arasbarani neglectus Dantchenko, 2000 as a valid name.

\section{Acknowledgements}

We thank Mark Kalashian (Scientific Center of Zoology and Hydrobiology, Yerevan, Armenia), Vahe Sargsyan (Arevik National Park, Meghri, Armenia), David Tarkhnishvili (Ilia State University, Tbilisi, Georgia), and Valentin Tikhonov (Russia, Pyatigorsk) for generous hospitality and help in butterflies collecting. Valentin Tikhonov provided also several samples important for this study. We also thank George Fayvush (Insti- 
tute of Botany, Yerevan, Armenia) for supplying us botanic literature and Andrei Sytin (Komarov Botanical Institute, St. Petersburg, Russia) for help in determination of $A s-$ tragalus species. The financial support for this study was provided by the grant N 14-1400541 from the Russian Science Foundation to the Zoological Institute of the Russian Academy of Sciences. The work was partially performed using equipment of the 'Chromas' Core Facility, the Centre for Molecular and Cell Technologies and the Department of Entomology of St. Petersburg State University. Some of this equipment was partly purchased with support of the St. Petersburg University grant 1.40.490.2017. 350 .

\section{References}

Banno Y, Kawaguchi Y, Koga K, Doira H (1995) Postreductional meiosis revealed in males of the mutant with chromosomal aberration "T $(23 ; 25) \mathrm{Nd}$ " of the silkworm, Bombyx mori. Journal of Sericultural Science of Japan 64: 410-414.

Bogdanov YF (2016) Inverted meiosis and its place in the evolution of sexual reproduction pathways. Russian Journal of Genetics 52(5): 473-490. https://doi.org/10.1134/ S1022795416050033

Carbonell F (1993) Contribution à la connaissance du genre Agrodiaetus Hübner (1822): le complexe ultraspécifique d'Agrodiaetus transcaspica Staudinger (1899) (Lepidoptera: Lycaenidae). Linneana Belgica 14: 89-116.

Carbonell F (2000) Contribution a la conaissance du genre Agrodiaetus Hübner (1822), A. barmifiruze n. sp. et $A$. musa esfahensis n. ssp, en Iran meridional. Linneana Belgica 17: 211-217.

Carbonell F (2001) Contribution à la connaissance du genre Agrodiaetus Hübner (1822), A. ahmadi et $A$. khorasanensis nouvelles espèces dans le Nord de l'Iran (Lepidoptera, Lycaenidae). Linneana Belgica 18: 105-110.

Carbonell F, Naderi AR (2000) Contribution a la connaissance du genre Agrodiaetus Hübner (1822) A. arasbarani n. sp. dans le nord-ouest de l'Iran (Lepidoptera, Lycaenidae). Linneana Belgica 17: 218-220.

Coutsis JG (1986) The blue butterflies of the genus Agrodiaetus Hübner (Lepidoptera, Lycaenidae): symptoms of taxonomic confusion. Nota Lepidopterologica 9: 159-169.

Dantchenko AV (2000a) Genus Agrodiaetus. In: Tuzov VK (Ed.) Guide to the butterflies of Russia and adjacent territories, Vol. 2. Pensoft, Sofia \& Moscow, 196-214.

Dantchenko AV (2000b) A new taxon of the genus Polyommatus Latreille, 1804 from the Transcaucasus (Lepidoptera, Lycaenidae). Neue Entomologische Nachrichten 48: 69-71.

Dantchenko AV (2005) A new species of the genus Agrodiaetus Hübner 1822 from Transcaucasia (Lepidoptera, Lycaenidae). Atalanta 35: 323-326, 472-473.

Dantchenko AV (2010) Systematics and phylogenetics of the Agrodiaetus blue butterflies of Russia and neighbouring countries (Lepidoptera, Lycaenidae). Ph.D. Dissertation, St. Petersburg, Russian Federation: St. Petersburg State University, Zoological Institute, Russian Academy of Sciences, 188 pp. [In Russian]

Dantchenko A, Churkin S (2003) A new species of the genus Polyommatus Latreille, 1804 from Mongolia (Lepidoptera, Lycaenidae). Neue Entomologische Nachrichten 54: 5-13. 
de Lesse H (1960a) Les nombres de chromosomes dans la classification du groupe d'Agrodiaetus ripartii Freyer (Lepidoptera, Lycaenidae). Revue Francaise d'Entomologie 27: 240-264. de Lesse H (1960b) Spéciation et variation chromosomique chez les Lépidoptères Rhopalocères. Annales des Sciences Naturelles Zoologie et Biologie Animale, 12e série. 2: 1-223.

de Lesse H (1963) Variation chromosomique chez les Agrodiaetus (Lep. Lycaenidae). Revue Francaise d'Entomologie 30: 182-189.

deWaard JR, Ivanova NV, Hajibabaei M, Hebert PDN (2008) Assembling DNA barcodes: analytical protocols. In: Martin CC (Ed.) Environmental Genomics, Methods in Molecular Biology. Humana Press, Totowa, New Jersey, 410: 275-283. https://doi.org/10.1007/9781-59745-548-0_15

Dincă V, Runquist M, Nilsson M, Vila R (2013) Dispersal, fragmentation and isolation shape: the phylogeography of the European lineages of Polyommatus (Agrodiaetus) ripartii (Lepidoptera: Lycaenidae). Biological Journal of the Linnean Society 109: 817-829. https://doi. org/10.1111/bij.12096

Eckweiler W, Bozano GC (2016) Guide to the butterflies of the Palearctic region. Lycaenidae part IV. Omnes artes, Milano, $132 \mathrm{pp}$.

Eckweiler W, Häuser CL (1997) An illustrated checklist of Agrodiaetus Hübner, 1822, a subgenus of Polyommatus Latreille, 1804 (Lepidoptera: Lycaenidae). Nachrichten des Entomologischen Vereins Apollo, Supplement 16: 113-168.

Faria R, Navarro A (2010) Chromosomal speciation revisited: rearranging theory with pieces of evidence. Trends in Ecology and Evolution 25: 660-669. https://doi.org/10.1016/j. tree.2010.07.008

Forster W (1956) Bausteine zur Kenntnis der Gattung Agrodiaetus Scudd. (Lep. Lycaen) I. Zeitschrift der Wiener Entomologischen Gesellschaft 41: 42-61, 70-89, 118-127.

Forster W (1960) Bausteine zur Kenntnis der Gattung Agrodiaetus Scudd. (Lep. Lycaen) II. Zeitschrift der Wiener Entomologischen Gesellschaft 45: 105-142.

Forster W (1961) Bausteine zur Kenntnis der Gattung Agrodiaetus Scudd. (Lep. Lycaen) II. Zeitschrift der Wiener Entomologischen Gesellschaft 46: 8-13, 38-47, 74-79, 88-94, 110-116.

Hajibabaei M, deWaard JR, Ivanova NV, Ratnasingham S, Dooph RT, Kirk SL, Mackie PM, Hebert PDN (2005) Critical factors for assembling a high volume of DNA barcodes. Philosophical Transactions of the Royal Society of London, Series B, Biological Sciences 360: 1959-1967. https://doi.org/10.1098/rstb.2005.1727

Hall TA (1999) BioEdit: a user-friendly biological sequence alignment editor and analysis program for Windows 95/98/NT. Nucleic Acids Symposium Series 41: 95-98.

Häuser C, Eckweiler W (1997) A catalogue of the species-group taxa in Agrodiaetus Hübner, 1822, a subgenus of Polyommatus Latreille, 1804 (Lepidoptera: Lycaenidae). Nachrichten des Entomologischen Vereins Apollo, Supplement 16: 53-112.

Heckmann S, Jankowska M, Schubert V, Kumke K, Ma W, Houben A (2014) Alternative meiotic chromatid segregation in the holocentric plant Luzula elegans. Nature Communications 5: 4979. https://doi.org/10.1038/ncomms5979

Hesselbarth G, Oorschot H, Wagener S (1995) Die Tagfalter der Türkei unter Berücksichtigung der angrenzenden Länder (Vol. 1-3). Selbstverlag Siegbert Wagener, Bocholt, 1354 pp. 
Ivanova NV, deWaard JR, Hebert PDN (2006) An inexpensive, automation-friendly protocol for recovering high quality DNA. Molecular Ecology Resources 6: 998-1002. https://doi. org/10.1111/j.1471-8286.2006.01428.x

Kandul NP, Lukhtanov VA, Pierce NE (2007) Karyotypic diversity and speciation in Agrodiaetus butterflies. Evolution 61(3): 546-559. https://doi.org/10.1111/j.15585646.2007.00046.x

Kandul NP, Lukhtanov VA, Dantchenko AV, Coleman JWS, Sekercioglu CH, Haig D, Pierce NE (2004) Phylogeny of Agrodiaetus Hübner 1822 (Lepidoptera: Lycaenidae) inferred from mtDNA sequences of COI and COII and nuclear sequences of EF1- 2 : Karyotype diversification and species radiation. Systematic Biology 53(2): 278-298. https://doi. org/10.1080/10635150490423692

Koçak A, Kemal M (2008) A replacement name for a preoccupied subspecies in Asiatic Lycaenidae (Lepidoptera). Miscallaneous Papers Centre for Entomological Studies Ankara 143: 7.

Lorković Z (1990) The butterfly chromosomes and their application in systematics and phylogeny. In: Kudrna O (Ed.) Butterflies of Europe, Vol. 2. Introduction to Lepidopterology. Aula-Verlag, Wiesbaden, 332-396.

Lukhtanov VA (1989) Karyotypes of some blue butterflies of the Agrodiaetus species groups (Lepidoptera, Lycaenidae). Annales Entomologici Fennici 55: 137-144.

Lukhtanov VA (2014) Chromosome number evolution in skippers (Lepidoptera, Hesperiidae). Comparative Cytogenetics 8(4): 275-291. https://doi.org/10.3897/CompCytogen. v8i4.8789

Lukhtanov VA (2015) The blue butterfly Polyommatus (Plebicula) atlanticus (Lepidoptera, Lycaenidae) holds the record of the highest number of chromosomes in the non-polyploid eukaryotic organisms. Comparative Cytogenetics 9(4): 683-690. https://doi.org/10.3897/ CompCytogen.v9i4.5760

Lukhtanov VA, Dantchenko AV (2002a) Descriptions of new taxa of the genus Agrodiaetus Hübner, [1822] based on karyotype investigation (Lepidoptera, Lycaenidae). Atalanta 33: 81-107, 224- 225.

Lukhtanov VA, Dantchenko AV (2002b) Principles of highly ordered metaphase I bivalent arrangement in spermatocytes of Agrodiaetus (Lepidoptera). Chromosome Research 10: 5-20. https://doi.org/10.1023/A:1014249607796

Lukhtanov VA, Tikhonov VV (2015) Chromosomal and molecular evidence for presence of Polyommatus (Agrodiaetus) poseidon (Lepidoptera, Lycaenidae) in Caucasus region. Comparative Cytogenetics 9(2): 249-255. https://doi.org/10.3897/CompCytogen.v9i2.5020

Lukhtanov VA, Shapoval NA (2017) Chromosomal identification of cryptic species sharing their DNA barcodes: Polyommatus (Agrodiaetus) antidolus and P. (A.) morgani in Iran (Lepidoptera, Lycaenidae). Comparative Cytogenetics 11(4): 759-768. https://doi. org/10.3897/CompCytogen.v11i4.20876

Lukhtanov VA, Pazhenkova EA, Novikova AV (2016a) Mitochondrial chromosome as a marker of animal migratory routes: DNA barcoding revealed Asian (non-African) origin of a tropical migrant butterfly Junonia orithya in south Israel. Comparative Cytogenetics 10(4): 671-677. https://doi.org/10.3897/CompCytogen.v10i4.11085 
Lukhtanov VA, Sourakov A, Zakharov EV (2016b) DNA barcodes as a tool in biodiversity research: testing pre-existing taxonomic hypotheses in Delphic Apollo butterflies (Lepidoptera, Papilionidae). Systematics and Biodiversity 14(6): 599-613. https://doi.org/10.1 080/14772000.2016.1203371

Lukhtanov VA, Shapoval NA, Dantchenko AV (2008) Agrodiaetus shahkuhensis sp. n. (Lepidoptera, Lycaenidae), a cryptic species from Iran discovered by using molecular and chromosomal markers. Comparative Cytogenetics 2(2): 99-114.

Lukhtanov VA, Shapoval NA, Dantchenko AV (2014) Taxonomic position of several enigmatic Polyommatus (Agrodiaetus) species (Lepidoptera, Lycaenidae) from Central and Eastern Iran: insights from molecular and chromosomal data. Comparative Cytogenetics 8(4): 313-322. https://doi.org/10.3897/CompCytogen.v8i4.8939

Lukhtanov VA, Vila R, Kandul NP (2006) Rearrangement of the Agrodiaetus dolus species group (Lepidoptera, Lycaenidae) using a new cytological approach and molecular data. Insect Systematics and Evolution 37(3): 325-334. https://doi.org/10.1163/187631206788838563

Lukhtanov VA, Dinca V, Talavera G, Vila R (2011) Unprecedented within-species chromosome number cline in the Wood White butterfly Leptidea sinapis and its significance for karyotype evolution and speciation. BMC Evolutionary Biology 11: 109. https://doi. org/10.1186/1471-2148-11-109

Lukhtanov VA, Dantchenko AV, Vishnevskaya MS, Saifitdinova AF (2015a) Detecting cryptic species in sympatry and allopatry: analysis of hidden diversity in Polyommatus (Agrodiaetus) butterflies (Lepidoptera: Lycaenidae). Biological Journal of the Linnean Society 116: 468-485. https://doi.org/10.1111/bij.12596

Lukhtanov VA, Shapoval NA, Anokhin BA, Saifitdinova AF, Kuznetsova VG (2015b) Homoploid hybrid speciation and genome evolution via chromosome sorting. Proceedings of the Royal Society B: Biological Sciences 282(1807): 20150157. https://doi.org/10.1098/rspb.2015.0157

Lukhtanov VA, Kandul NP, Plotkin JB, Dantchenko AV, Haig D, Pierce NE (2005) Reinforcement of pre-zygotic isolation and karyotype evolution in Agrodiaetus butterflies. Nature 436: 385-389. https://doi.org/10.1038/nature03704

Maddison WP, Maddison DR (2015) Mesquite: a modular system for evolutionary analysis. Version 3.04. http://mesquiteproject.org

Manicardi GC, Mandrioli M, Blackman RL (2015) The cytogenetic architecture of the aphid genome. Biological Reviews 90: 112-125. https://doi.org/10.1111/brv.12096

Nokkala S, Kuznetsova VG, Maryanska-Nadachowska A, Nokkala C (2006) Holocentric chromosomes in meiosis. II. The modes of orientation and segregation of a trivalent. Chromosome Research 14: 559-565. https://doi.org/10.1007/s10577-006-1053-6

Olivier A, Puplesiene J, van der Pooten D, De Prins W, Wiemers M (1999) Revision of some taxa of Polyommatus (Agrodiaetus) transcaspicus group with description of a new species from Central Anatolia (Lepidoptera, Lycaenidae). Phegea 27(1): 1-24.

Przybyłowicz L (2000) Polish butterflies of the subgenus Polyommatus (Agrodiaetus) (Lepidoptera: Lycaenidae). Polish Journal of Entomology 69: 329-334.

Przybyłowicz L (2014) Polyommatus ripartii: The biological basis for the conservation and the morphology of the developmental stages of a critically endangered, relict population in Central Europe. Journal of Insect Science 14: 1-8. https://doi.org/10.1093/jisesa/ieu109 
Przybyłowicz Ł, Lukhtanov VA, Lachowska-Cierlik D (2014) Towards the understanding of the origin of the Polish remote population of Polyommatus (Agrodiaetus) ripartii (Lepidoptera: Lycaenidae) based on karyology and molecular phylogeny. Journal of Zoological Systematics and Evolutionary Research 52: 44-51. https://doi.org/10.1111/jzs.12040

Ronquist F, Teslenko M, van der Mark P, Ayres DL, Darling A, Höhna S, Larget B, Liu L, Suchard MA, Huelsenbeck JP (2012) MrBayes 3.2: efficient Bayesian phylogenetic inference and model choice across a large model space. Systematic Biology 61: 539-542. https://doi.org/10.1093/sysbio/sys029

Schurian K, ten Hagen W (2003) Polyommatus (Agrodiaetus) urmiaensis sp. n. aus Nordwestiran (Lepidoptera: Lycaenidae). Nachrichten des Entomologischen Vereins Apollo 24(1/2): 1-5. Shapoval NA, Lukhtanov VA (2015a) Taxonomic interpretation of chromosomal and mitochondrial DNA variability in the species complex close to Polyommatus (Agrodiaetus) dama (Lepidoptera, Lycaenidae). ZooKeys 538: 1-20. https://doi.org/10.3897/zookeys.538.6559 Shapoval NA, Lukhtanov VA (2015b) Taxonomic position and status of Polyommatus (Agrodiaetus) iphigenia (Lepidoptera, Lycaenidae) from the Peloponnese, Southern Greece. Folia Biologica-Krakow 63(4): 295-300. https://doi.org/10.3409/fb63_4.295

Shapoval N, Lukhtanov V (2016) On the generic position of Polyommatus avinovi (Lepidoptera: Lycaenidae). Folia Biologica (Kraków) 64(4): 267-273. https://doi.org/10.3409/fb64_4.267

Šíchová J, Voleníková A, Dincă V, Nguyen P, Vila R, Sahara K, Marec F (2015) Dynamic karyotype evolution and unique sex determination systems in Leptidea wood white butterflies. BMC Evolutionary Biology 15: 89. https://doi.org/10.1186/s12862-015-0375-4

Šíchová J, Ohno M, Dincă V, Watanabe M, Sahara K, Marec F (2016) Fissions, fusions, and translocations shaped the karyotype and multiple sex chromosome constitution of the northeast-Asian wood white butterfly, Leptidea amurensis. Biological Journal of the Linnean Society 118: 457-471. https://doi.org/10.1111/bij.12756

Skala P (2001) New taxa of the subgenus Agrodiaetus Hübner, 1822 from Iran Polyommatus (Agrodiaetus) faramarzii sp. n., $P$. (A.) shahrami sp. n. and $P$. (A.) pfeifferi astyages ssp. n. (Lepidoptera, Lycaenidae). Nachrichten des Entomologischen Vereins Apollo 22(2): 101-108.

Stradomsky BV, Arzanov YG ([2000]) Polyommatus elena sp. n. and Polyommatus neglectus sp. n. - new taxones of the family Lycaenidae (Lepidoptera). Izvestiya Kharkovskogo Entomologicheskogo Obschestva 7(2): 17-21.

Stradomsky BV, Fomina ES (2013) The comparison of taxa Polyommatus yurinekrutenko Kocak, 1996 and P. shamil (Dantchenko, 2000) (Lepidoptera: Lycaenidae). Caucasian Entomological Bulletin 9(1): 181-182.

Talavera G, Lukhtanov VA, Pierce NE, Vila R (2013) Establishing criteria for higher-level classification using molecular data: the systematics of Polyommatus blue butterflies (Lepidoptera, Lycaenidae). Cladistics 29: 166-192. https://doi.org/10.1111/j.1096-0031.2012.00421.x ten Hagen W, Eckweiler W (2001) Eine neue Art von Polyommatus (Agrodiaetus) aus Zentraliran (Lepidoptera, Lycaenidae). Nachrichten des Entomologischen Vereins Apollo 22(2): 53-56. Vershinina AO, Lukhtanov VA (2010) Geographical distribution of the cryptic species Agrodiaetus alcestis alcestis, $A$. alcestis karacetinae and $A$. demavendi (Lepidoptera, Lycaenidae) revealed by cytogenetic analysis. Comparative Cytogenetics 4(1): 1-11. https://doi. org/10.3897/compcytogen.v4i1.21 
Vershinina AO, Lukhtanov VA (2013) Dynamics of chromosome number evolution in the Agrodiaetus phyllis species complex (Insecta: Lepidoptera). Cell and Tissue Biology 7(4): 379-381. https://doi.org/10.1134/S1990519X13040159

Vershinina AO, Lukhtanov VA (2017) Evolutionary mechanisms of runaway chromosome number change in Agrodiaetus butterflies. Scientific Reports 7: 8199. https://doi. org/10.1038/s41598-017-08525-6

Vershinina AO, Anokhin BA, Lukhtanov VA (2015) Ribosomal DNA clusters and telomeric (TTAGG)n repeats in blue butterflies (Lepidoptera, Lycaenidae) with low and high chromosome numbers. Comparative Cytogenetics 9(2): 161-171. https://doi.org/10.3897/ CompCytogen.v9i2.4715

Vila R, Lukhtanov VA, Talavera G, Gil-T F, Pierce NE (2010) How common are dot-like distribution ranges? Taxonomical oversplitting in Western European Agrodiaetus (Lepidoptera, Lycaenidae) revealed by chromosomal and molecular markers. Biological Journal of the Linnean Society 101: 130-154. https://doi.org/10.1111/j.1095-8312.2010.01481.x

Vishnevskaya MS, Saifitdinova AF, Lukhtanov VA (2016) Karyosystematics and molecular taxonomy of the anomalous blue butterflies (Lepidoptera, Lycaenidae) from the Balkan Peninsula. Comparative Cytogenetics 10(5): 1-85. https://doi.org/10.3897/CompCytogen.v10i5.10944

Wiemers M (2003) Chromosome differentiation and the radiation of the butterfly subgenus Agrodiaetus (Lepidoptera: Lycaenidae: Polyommatus) a molecular phylogenetic approach. Ph.D. Dissertation, University of Bonn, Bonn, Germany, 203 pp. http://nbn-resolving. de/urn:nbn:de:hbz:5n-02787

Wiemers M, Fiedler K (2007) Does the DNA barcoding gap exist? - a case study in blue butterflies (Lepidoptera: Lycaenidae). Frontiers in Zoology 4: 8. https://doi.org/10.1186/17429994-4-8

Wiemers M, Keller A, Wolf M (2009) ITS2 secondary structure improves phylogeny estimation in a radiation of blue butterflies of the subgenus Agrodiaetus (Lepidoptera: Lycaenidae: Polyommatus). BMC Evolutionary Biology 9: 300. https://doi.org/10.1186/1471-2148-9-300

\section{Supplementary material I}

\section{Table S1}

Authors: Vladimir A. Lukhtanov, Alexander V. Dantchenko

Data type: PDF table.

Explanation note: Chromosome numbers of the studied Polyommatus (Agrodiaetus) samples with their IDs, localities, dates and collectors.

Copyright notice: This dataset is made available under the Open Database License (http://opendatacommons.org/licenses/odbl/1.0/). The Open Database License $(\mathrm{ODbL})$ is a license agreement intended to allow users to freely share, modify, and use this Dataset while maintaining this same freedom for others, provided that the original source and author(s) are credited.

Link: https://doi.org/10.3897/CompCytogen.v11i4.20072.suppl1 